\title{
Anticancer activity of biogenerated silver nanoparticles: an integrated proteomic investigation
}

\author{
Miriam Buttacavoli ${ }^{1, *}$, Nadia Ninfa Albanese ${ }^{1, *}$, Gianluca Di Cara ${ }^{2}$, Rosa Alduina ${ }^{1}$, \\ Claudia Faleri ${ }^{3}$, Michele Gallo ${ }^{4}$, Giuseppe Pizzolanti ${ }^{5,6}$, Giuseppe Gallo ${ }^{1,6}$, Salvatore \\ Feo $^{1,6}$, Franco Baldi ${ }^{4}$ and Patrizia Cancemi ${ }^{1,2,6}$ \\ ${ }^{1}$ Department of Biological Chemical and Pharmaceutical Sciences and Technologies (STEBICEF), University of Palermo, \\ Palermo, Italy \\ ${ }^{2}$ Center of Experimental Oncobiology (C.OB.S.), La Maddalena Hospital III Level Oncological Dept., Palermo, Italy \\ ${ }^{3}$ Department of Life Science, University of Siena, Siena, Italy \\ ${ }^{4}$ Department of Molecular Science and Nanosystems, Cà Foscari University of Venice, Venice, Italy \\ ${ }^{5}$ Biomedical Department of Internal and Specialist Medicine (DIBIMIS), Section of Endocrinology, University of Palermo, \\ Palermo, Italy \\ ${ }^{6}$ Advanced Technologies Network Center (ATeN), University of Palermo, Palermo, Italy \\ *These authors contributed equally to this work
}

Correspondence to: Patrizia Cancemi, email: patrizia.cancemi@unipa.it

Keywords: silver nanoparticles (AgNPs); bacteria; breast cancer cells; anticancer activity; proteomics

Received: May 27, $2017 \quad$ Accepted: October 30, $2017 \quad$ Published: December 23, 2017

Copyright: Buttacavoli et al. This is an open-access article distributed under the terms of the Creative Commons Attribution License 3.0 (CC BY 3.0), which permits unrestricted use, distribution, and reproduction in any medium, provided the original author and source are credited.

\section{ABSTRACT}

Silver nanoparticles (AgNPs), embedded into a specific polysaccharide (EPS), were biogenerated by Klebsiella oxytoca DSM 29614 under aerobic (AgNPs-EPS ${ }^{a e r}$ ) and anaerobic conditions (AgNPs-EPS anaer). Both AgNPs-EPS matrices were tested by MTT assay for cytotoxic activity against human breast (SKBR3 and 8701-BC) and colon (HT-29, HCT 116 and Caco-2) cancer cell lines, revealing AgNPs-EPS aer as the most active, in terms of IC50, with a more pronounced efficacy against breast cancer cell lines. Therefore, colony forming capability, morphological changes, generation of reactive oxygen species (ROS), induction of apoptosis and autophagy, inhibition of migratory and invasive capabilities and proteomic changes were investigated using SKBR3 breast cancer cells with the aim to elucidate AgNPs-EPS aer mode of action. In particular, AgNPs-EPS aer induced a significant decrease of cell motility and MMP-2 and MMP-9 activity and a significant increase of ROS generation, which, in turn, supported cell death mainly through autophagy and in a minor extend through apoptosis. Consistently, TEM micrographs and the determination of total silver in subcellular fractions indicated that the $\mathrm{Ag}^{+}$accumulated preferentially in mitochondria and in smaller concentrations in nucleus, where interact with DNA. Interestingly, these evidences were confirmed by a differential proteomic analysis that highlighted important pathways involved in AgNPs-EPS ${ }^{a e r}$ toxicity, including endoplasmic reticulum stress, oxidative stress and mitochondrial impairment triggering cell death trough apoptosis and/or autophagy activation.

\section{INTRODUCTION}

Cancer is a multifaceted disease, extremely variable in its presentation, development and outcome. It is well established that cancer is a multifactorial disease caused by a complex mixture of genetic and environmental factors. However the knowledge of the genetic, molecular, and cellular basis of cancer can provide new targets and strategies for therapy. Many anticancer drugs are unable to reach their target site in sufficient concentrations and efficiently exert the pharmacological effect without causing irreversible unwanted injury to healthy tissues 
and cells [1-3]. Nanotechnology offers a wealth of tools to treat cancer by passing biological barriers to deliver therapeutic agents directly [4]. The unique physicochemical characteristics of metal NPs, such as high surface-to-volume ratio, broad optical properties, ease of synthesis and surface functionalization offer new opportunities for cancer therapeutics. The production of silver nanoparticles (AgNPs) has become the object of intense research and several methods have been developed to synthesize noble metal NPs, including physical and chemical ones [5-7].

The biological synthesis of AgNPs have received increasing attention due to the growing need of developing eco-friendly (i. e. "green") technologies in material synthesis [6,8-12]. Thus, different microorganisms, either bacteria or fungi, have been used as potential cell-factories for both intra and extra cellular production of AgNPs $[9,13]$. The mechanism of biological formation of metal-NPs is mainly due to the capability of biopolimers and, in particular, microbial exopolysaccharides (EPS) to act as metal reducers and/ or stabilizers [14-16]. The Klebsiella oxytoca DSM 29614 EPS is composed of a branched heptasaccharide repeating unit (1 galactose, 4 rhamnoses, 2 glucuronic acids), with metal binding properties during the fermentative biosynthetic process $[17,18]$. K. oxytoca strains are ubiquitous bacteria mainly studied as opportunistic pathogens which are responsible for nosocomial infections [19]. However, many $K$. oxytoca strains are also known to produce exopolysaccharides of environmental and pharmaceutical interest [17, 20]. Furthermore, the production of other metal nanoparticles embedded in this EPS has already been reported [21-25].

In this study, we tested the anticancer effect of biogenerated AgNPs-EPS on different cancer cell lines, and then investigated its molecular mechanism of action in the SKBR3 breast cancer cell line. In particular, we found that AgNPs-EPS ${ }^{\text {aer }}$ caused: i) a significant decrease of cell viability and motility, ii) an impairment of MMP-2 and MMP-9 activity, and iii) a promotion of ROS generation, which, in turn, induced cell death through apoptosis and autophagy. These evidences were confirmed by a differential proteomic analysis, in which proteomic changes are consistent with the activation of important pathways including endoplasmic reticulum stress, oxidative stress and mitochondrial disfunction triggering cell death trough apoptosis and/ or autophagy activation. Finally, TEM micrographs and the determination of total silver in subcellular fractions reinforce the idea that $\mathrm{Ag}^{+}$released from $\mathrm{AgNPs}-\mathrm{EPS}^{\text {aer }}$ firstly in mitochondria and then in nuclei determines cell damage and death.

To the best of our knowledge, this is the first study reporting the mechanism of action of biosynthesized AgNPs through an integrated proteomic approach.

\section{RESULTS}

\section{Cytotoxic effects of AgNPs-EPS}

The cytotoxic effect of AgNPs biogenerated by Klebsiella oxytoca DSM 29614 under aerobic (AgNPsEPS $^{\text {aer }}$ ) and anaerobic conditions (AgNPs-EPS ${ }^{\text {anaer }}$ ) was investigated after $24 \mathrm{~h}$ of treatment on two human breast cancer cell lines (SKBR3 and 8701-BC) and three human colon cancer cell lines (HT-29, HCT 116 and Caco-2) by using the MTT assay. The results, expressed as $\mathrm{IC}_{50}$ values, calculated from the dose-survival curves, are reported in Table 1. The AgNPs-EPS aer is more active than AgNPsEPS anaer, with SKBR3 and 8701-BC cell lines being more sensitive to AgNPs-EPS ${ }^{\text {aer }}$ treatment in comparison to HT-29, HCT 116 and Caco-2 colon cancer cell lines. In particular, SKBR3 cells proliferation was significantly inhibited by AgNPs-EPS ${ }^{\text {aer }}$ with an $\mathrm{IC}_{50}$ value of $5 \mu \mathrm{g} / \mathrm{ml}$, while an $\mathrm{IC}_{50}$ value of $8 \mu \mathrm{g} / \mathrm{ml}$ was found for $8701-\mathrm{BC}$ cell line. These values were found well within the clinically acceptable concentration of $100 \mu \mathrm{g} / \mathrm{ml}$ [26], suggesting a potential anticancer effect of both biogenerated AgNPsEPS. Since AgNPs-EPS ${ }^{\text {aer }}$ contains more total silver than AgNPs-EPS anaer [24] and the amount of $\mathrm{Ag}^{+}$released from AgNPs-EPS ${ }^{\text {aer }}$ is significantly higher than for AgNPsEPS anaer [25], we believe that the biological activity of AgNPs-EPS is Ag-dependent. None toxic effect was observed for metal-free EPS.

Since AgNPs-EPS ${ }^{\text {aer }}$ had the highest cytotoxic activity towards breast cancer SKBR3 cells, the selectivity index (SI) was investigated by using a non tumoral mammary epithelial cell line (HB2), as previously reported [27]. Cytotoxic assays were performed for $24 \mathrm{~h}$ and $48 \mathrm{~h}$, and doxorubicin was used as a positive control (Table 2). The SI were quite similar between AgNPs-EPS ${ }^{\text {aer }}$ and doxorubicin, a commonly used chemotherapeutic drug [28]. Moreover, this investigation revealed high selectivity for SKBR3 cells [29], with higher SI value for higher treatment time, being SI 3.4 and 5.0 after 24 and $48 \mathrm{~h}$, respectively. Based on these results, SKBR3 cells were further used to study the mechanisms of cytotoxicity associated with the AgNPs-EPS treatments.

\section{Colony formation assay}

In order to assess SKBR3 cell viability in terms of reproductive capacity after treatments with the two kinds of AgNPs-EPS, a colony formation assay was performed [30]. To this aim, cells were seeded in appropriate dilutions and treated with two different concentrations (50 and 5 $\mu \mathrm{g} / \mathrm{ml}$ ) for 1 and $24 \mathrm{~h}$, maintained under normal culture conditions and analysed two weeks later for the formation of colonies. The results (Figure 1) showed that AgNPsEPS $^{\text {aer }}$ treatment inhibited significantly the colony-forming ability of SKBR3 cells in a dose- and time-dependent manner and, interestingly, resulted effective already 
Table 1: $\mathrm{IC}_{50}$ values at $24 \mathrm{~h}$ of Ag-NPs-EPS in selected cancer cell lines

\begin{tabular}{lccc}
\hline & & $\mathbf{I C}_{\boldsymbol{5 0}}(\boldsymbol{\mu g} / \mathbf{m l}) \pm \mathbf{S D}$ & \\
\cline { 2 - 4 } & AgNPs-EPSanaer & AgNPs-EPSaer & Metal free-EPS \\
\hline SKBR3 & $50 \pm 1.5$ & $5 \pm 0.5$ & NA \\
$8701-B C$ & $75 \pm 1.3$ & $8.2 \pm 0.8$ & NA \\
HT29 & NA & $20 \pm 2$ & NA \\
HCT116 & NA & $26 \pm 2$ & NA \\
CaCo2 & NA & $34 \pm 4$ & NA \\
\hline
\end{tabular}

Table 2: $\mathrm{IC}_{50}$ values calculated at 24 and $48 \mathrm{~h}$ of AgNPs-EPSaer treatment, in SKBR3 breast cancer cell line and in the non tumoral epithelial mammary cell line HB2

\begin{tabular}{|c|c|c|c|c|c|c|}
\hline & \multicolumn{2}{|c|}{$\mathrm{HB} 2 \mathrm{IC}_{50} \pm \mathrm{SD}$} & \multicolumn{2}{|c|}{$\mathrm{SKBR3} \mathrm{IC}_{50} \pm \mathrm{SD}$} & \multicolumn{2}{|c|}{$\begin{array}{c}\text { Selectivity index SI } \\
\left(\mathrm{HB}^{\mathrm{I} I C_{50}} / \mathrm{SKBR}_{\mathrm{IC}} \mathrm{IC}_{50}\right.\end{array}$} \\
\hline & $24 \mathrm{~h}$ & $48 \mathrm{~h}$ & $24 \mathrm{~h}$ & $48 \mathrm{~h}$ & $24 \mathrm{~h}$ & $48 \mathrm{~h}$ \\
\hline AgNPsaer & $17 \pm 0.5^{\mathrm{a}}$ & $9 \pm 0.8^{a}$ & $5 \pm 0.5^{\mathrm{a}}$ & $1.8 \pm 0.8^{\mathrm{a}}$ & 3.4 & 5 \\
\hline Doxorubicin & $15.8 \pm 2,1^{\mathrm{b}}$ & $5.3 \pm 1^{\mathrm{b}}$ & $4.1 \pm 0.5^{\mathrm{b}}$ & $1.12 \pm 0.1^{\mathrm{b}}$ & 3.8 & 4.8 \\
\hline
\end{tabular}

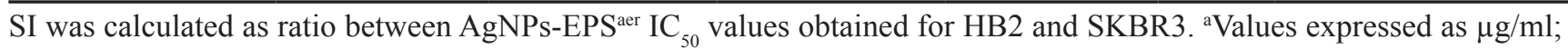
${ }^{b}$ values expressed as $\mu \mathrm{M}$.

after 1 h-treatment. On the other hand, AgNPs-EPS ${ }^{\text {anaer }}$ treatment inhibited cell proliferation in a dose- and timedependent manner only at the highest dose of $50 \mu \mathrm{g} / \mathrm{ml}$. Thus, according MTT assay results, AgNPs-EPS ${ }^{\text {aer }}$ exerts a superior biocide activity in comparison to AgNPs-EPS ${ }^{\text {anaer }}$. None effect was observed for free-metal EPS.

\section{AgNPs-EPS inhibit motility and MMPs activity in SKBR3 cells}

Migration and invasion represent a cancer progression hallmark [31], so we tested the effect of Ag-NPs-EPS on cell motility by performing a wound-
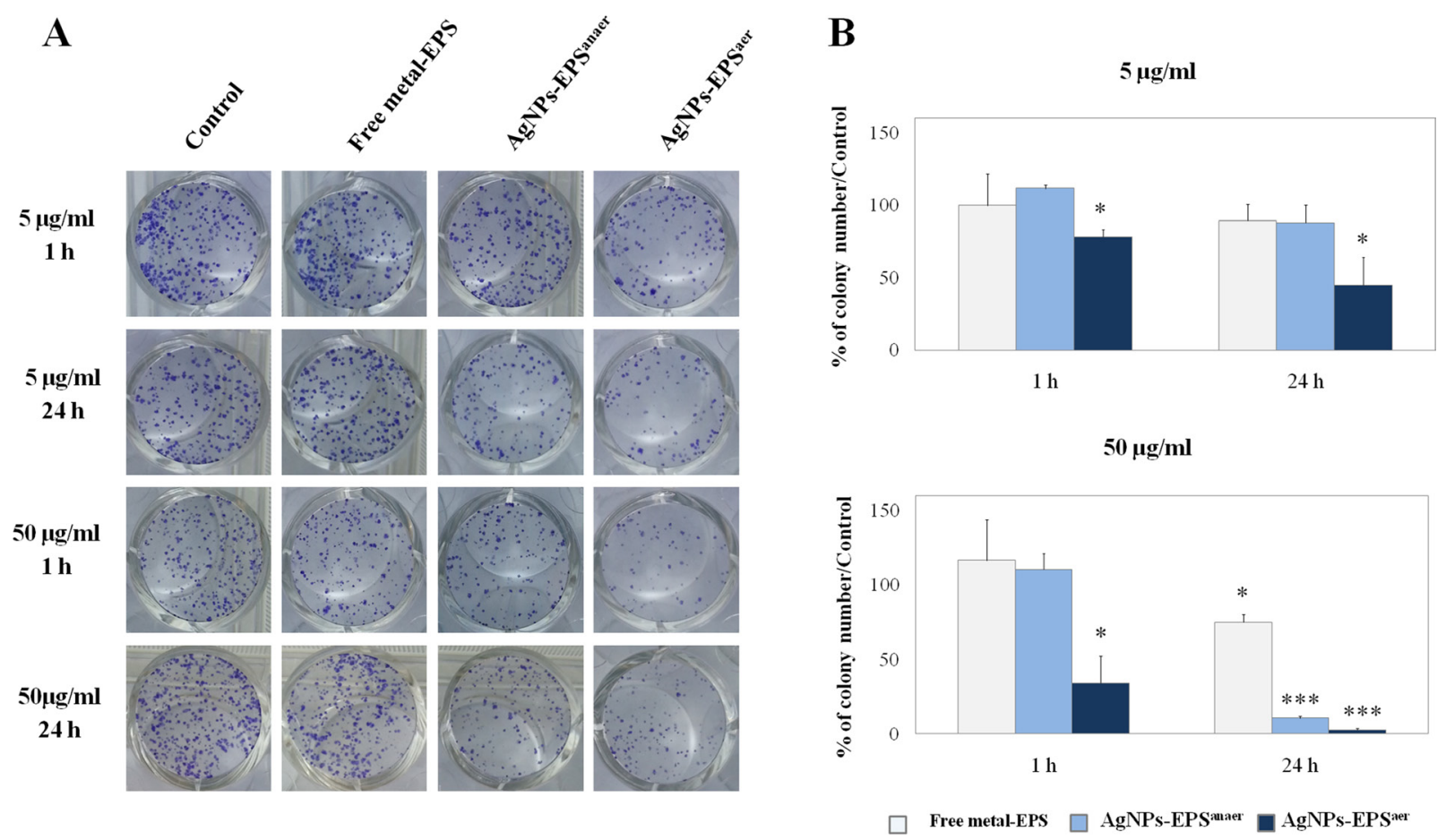

Figure 1: Cytotoxic effect of AgNPs-EPS in SKBR3 cells evaluated by clonogenic assay. (A) Culture dishes with stained colonies of a representative experiment; (B) Statistical results of colony-forming assays presented as percentage of colonies numbers in the respect of untreated cells used as control. Statistical significance was assessed by the Student's $t$-test: " $p<0.05$ was considered significant; ${ }^{* * *} p<0.001$ very highly significant. The data in the graphs are expressed as mean number $\pm \mathrm{SD}$ of three different experiments. 
healing assay. Results (Figure 2A) showed an inhibition of migratory ability both at 6 and $24 \mathrm{~h}$ in AgNPs-EPS ${ }^{\text {aer }}$ treated cells. AgNPs-EPS ${ }^{\text {anaer }}$ treatment did not affect significantly the migratory capability of SKBR3 cells. Cell migration represent a complex process that involves the expression of a number of growth factors, cytokines and matrix metalloproteinases (MMPs) $[32,33]$. Because of the significant effects induced by AgNPs-EPS ${ }^{\text {aer }}$ on cell migration, we evaluated the effects on MMP-2 and MMP9 enzymatic activities and protein expression in SKBR3 cells using gelatin zymography and western blot. Data revealed a significant decrease of enzymatic activities in AgNPs-EPS ${ }^{\text {aer }}$ treated cells with the maximum effect for pro MMP-9 that is almost disappeared. AgNPs-EPS anaer (Figure 2B, 2C and 2D) treatment instead did not affect significantly the activity levels of MMPs, accordingly to the scratch assay results.

\section{Morphological assessment of SKBR-3 cells treated with both AgNPs-EPS}

The morphology of SKBR3 cells treated with either AgNPs-EPS aer and AgNPs-EPS ${ }^{\text {anaer }}$ were significantly changed in comparison to the untreated control cells: treated

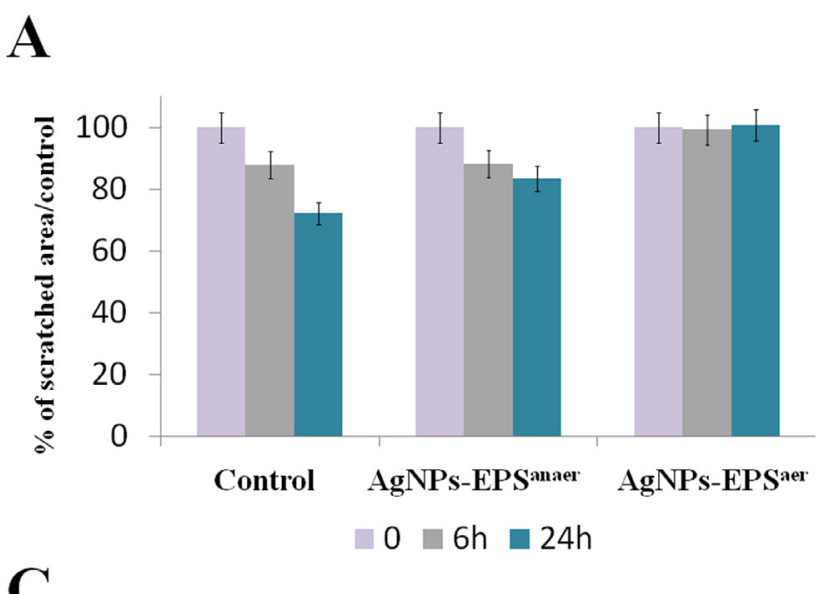

C

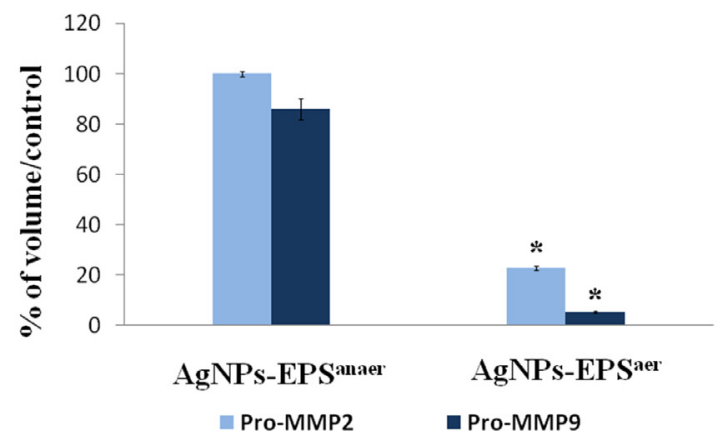

cells showed apoptotic-like symptoms such as cell shrinkage and detachment from the adjacent cells especially in the case of AgNPs-EPS ${ }^{\text {aer }}$ treatment. Moreover, irregularity in shape, cytoplasmic blebbing, intracellular vacuoles, cellular debris and nuclear chromatin condensation were clearly observed (Figure 3A). No morphological changes were observed for free-metal EPS (data not shown). AO/EB staining technique was used to verify whether the AgNPs-EPS-cell death is due to apoptotic induction or unspecific necrosis. As expected (Figure 3B), the control cells emitted only green fluorescence due to the AO staining. On the contrary, the AgNPs-EPS treated cells exhibited orange fluorescence (sensitive to $\mathrm{pH}$ lowering) due to the loss in membrane integrity. In particular, in AgNPs-EPS ${ }^{\text {anaer }}$ treated cells, only membrane blebbing and condensed chromatin were observed, while in AgNPsEPS $^{\text {aer }}$ treated cells, loss of membrane integrity, condensed chromatin and nuclei stained with EB, were observed.

\section{Effect of AgNPs-EPS treatment on intracellular oxygen species}

Elevation of intracellular ROS levels is known to induce oxidative stress and cell death [34, 35]. Several studied reported that AgNP cytotoxicity is primarily

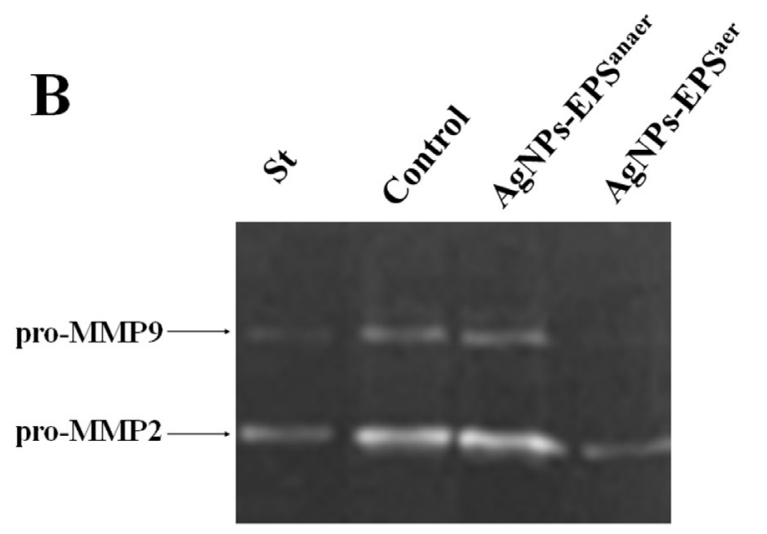

D

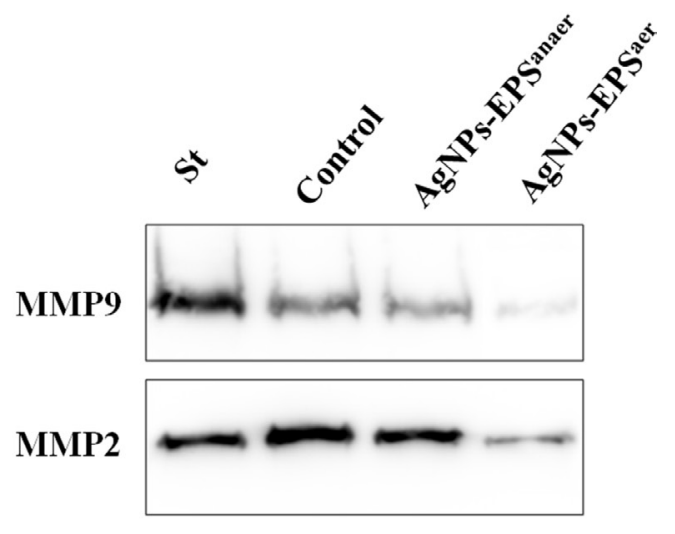

Figure 2: AgNPs-EPS ${ }^{\text {aer }}$ inhibit wound healing and MMP9/MMP2 activity in SKBR3 cells. (A) Inhibitory effect on cell migration assessed by wound healing assay and quantified by measuring the scratched area. (B) Zymographic analysis of MMP9 and MMP2 activity in SKBR3 cells. The gelatinolytic bands correspond to the pro MMP9 and pro MMP2. (C) Densitometric analyses of proMMP2 and MMP9 secretion. Statistical significance was assessed by the Student's $t$-test: ${ }^{*} p<0.001$. The data in the graphs are expressed as mean of the band-intensity \pm SD. (D) Western blot validation of MMP9 and MMP2 protein expression in conditioned media. 
the result of oxidative stress [36, 37], which in turn induces cell death through several supposed molecular mechanisms such as activation of intrinsic pathway of apoptosis, autophagy or both [38-41]. We investigated the effect of AgNPs-EPS on intracellular levels of ROS by dichlorodihydrofluorescein diacetate (DCFH-DA) and Dihydroethidium (DHE) assays, two generic indicators of cellular ROS levels. As shown in Figure 4, after 24 $\mathrm{h}$ of exposure AgNPs-EPS ${ }^{\text {aer }}$ induced a remarkable ROS increase in a concentration-dependent manner. Compared to the control cells, a maximum of 2.25 and 1.75 fold increases in ROS generation was observed with $10 \mu \mathrm{g} / \mathrm{ml}$ concentration of AgNPs-EPS ${ }^{\text {aer }}$ treatment, in DCFH-DA and DHE assay respectively, suggesting an important role of ROS in cell death induction. AgNPs-EPS ${ }^{\text {anaer }}$ treatment did not affect significantly intracellular levels of ROS in comparison to the control cells.

\section{Detection of Apoptosis and autophagy}

We examined whether AgNPs-EPS-induced cell death occurs via apoptosis, autophagy, or both. Flow cytometry analysis (Figure 5A) revealed that only the $11.57 \%$ of AgNPs-EPS ${ }^{\text {aer }}$ treated cells underwent to apoptosis compared to the $5.50 \%$ in untreated cells and doxorubicin treated cells (27.81\%), while no apoptosis was recorded for AgNPs-EPS ${ }^{\text {anaer }}$ treated cells (5.58\%) and for free-metal EPS treated cells (6.06\%). Accordingly, no DNA fragmentation was evident in SKBR3 cells after $24 \mathrm{~h}$ of AgNPs-EPS exposure (Figure 5B), suggesting that apoptosis was not prominent in AgNPs-EPS ${ }^{\text {aer }}$-induced cell death, at least in the first $24 \mathrm{~h}$ of treatment. Therefore, three different staining specific for lysosomal/vacuolar activity include Lysotracker $^{\circledR}$ (a fluorescent acidotropic probe used for labeling acidic organelles in live cells such as lysosomes/ vacuoles), MonoDansylCadaverine (MDC) (a weak base able to label autophagosomes and autolysosomes) and Acridine Orange (AO) (a fluorescent basic dye that accumulates in acidic compartments, such as lysosomes and vacuole) were used to investigate autophagy. AgNPs-EPS ${ }^{\text {aer }}$ treated cells (Figure 5C) showed autophagolysosomes in the cytoplasm detected by fluorescence microscopy as bright punctate dots $[42,43]$. Moreover the expression of autophagic markers such as AKT, p-AKT, ATG5, ATG7, HSP90, P62, LC3I/II protein and beclin I, were analyzed by Western blot (Figure 5D). As expected, we observed a concomitant down regulation of AKT, p-AKT, p62 and HSP90 expression and an up-regulation of ATG5, ATG7, LC3-II and beclin-1 in AgNPs-EPS ${ }^{\text {aer }}$ treated cells, indicating a prominent mechanism of autophagic cell death.

\section{Effect of AgNPs-EPS on SKBR3 proteome}

Differential proteomic analysis (2D-DIGE) was performed to detect protein modulations induced by both AgNPs-EPS on SKBR-3 cells, after $24 \mathrm{~h}$ of treatments

\section{A}

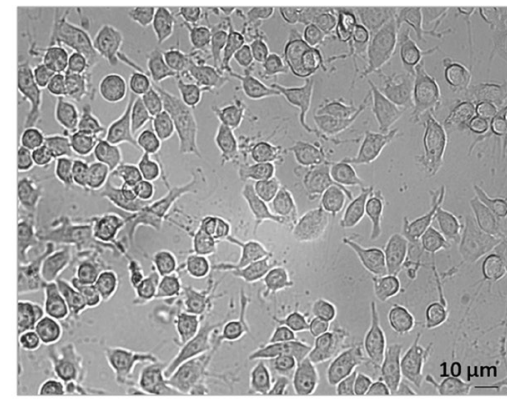

B

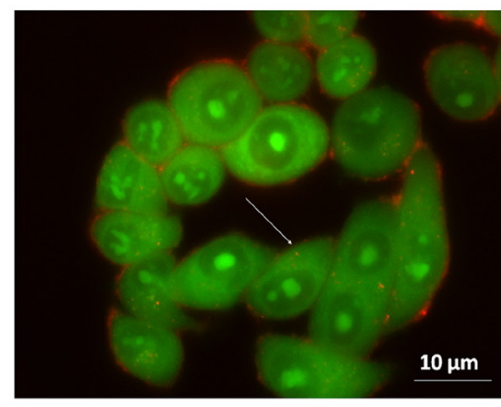

Control
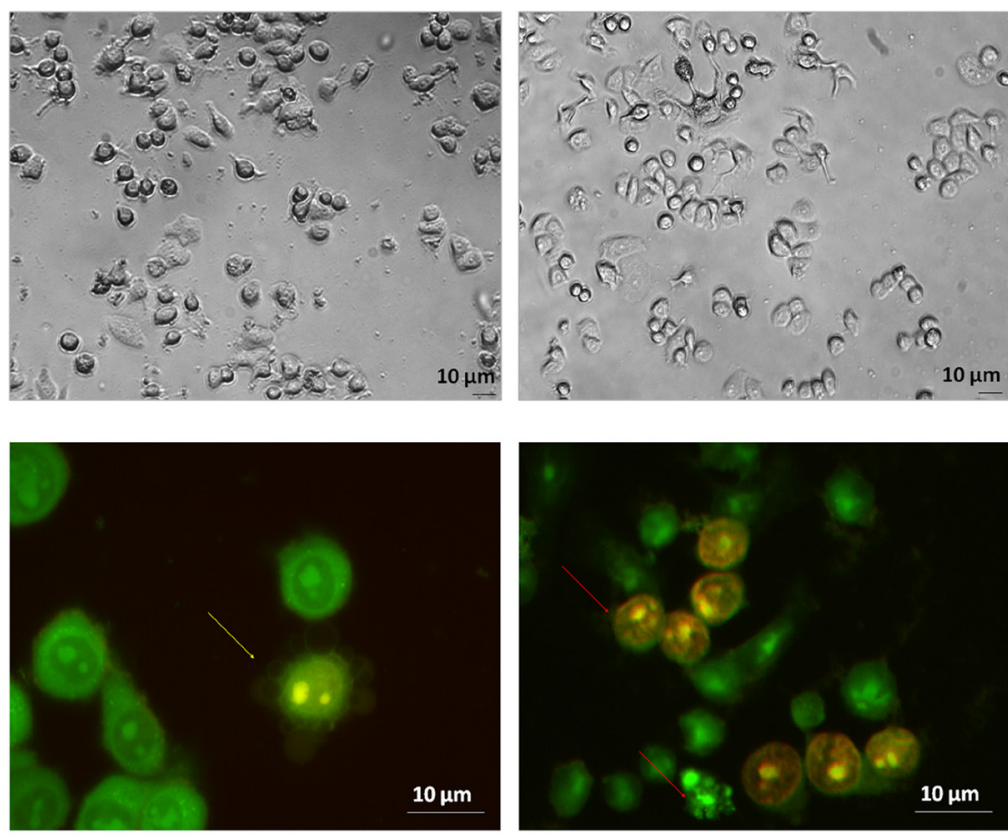

AgNPs-EPS anaer

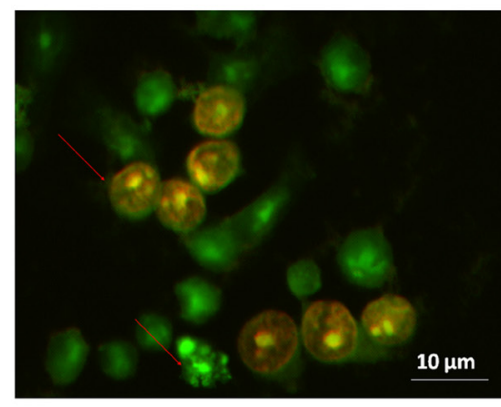

AgNPs-EPS ${ }^{\text {aer }}$

Figure 3: Morphological changes in SKBR3 cells treated with AgNPs-EPS. (A) Inverted phase-contrast micrographs Magnification 200X. (B) Fluorescence microscope micrographs after AO/EB double staining. Magnification 680X. Viable cells (blank arrow), membranes blebbing (yellow arrow), loss of membrane integrity, condensed chromatin and nuclei stained with EB (red arrows). Each experiment was performed in triplicate $(n=3)$ and generated similar morphological features. 
in order to unveiling molecular pathways involved in AgNPs-EPS ${ }^{\text {aer }}$ cytotoxicity. A total of six gels were run to achieve a statistically significant measure of the differences in protein expression between the analyzed groups. Protein spots were quantified, normalized and inter-gel matched and only differentially expressed proteins with the threshold settings with at least fold change $\geq 1.3$ and $p$-value $<0.01$, were considered regulated (Supplementary Table 1). Figure 6A shows a prototype of proteomic map of SKBR3 cells with 253 labels corresponding to the protein spots showed a significant difference. Among the differentially expressed spots (Figure 6B), 202, corresponding to $80 \%$, were selectively modulated in AgNPs-EPS ${ }^{\text {aer }}$ treated cells, only two proteins spots were modulated selectively in AgNPs-EPS ${ }^{\text {anaer }}$ and only two in EPS free metal treated cells, confirming the prominent biological activity of AgNPs-EPS ${ }^{\text {aer }}$. Overlapping modulations are shown, also. The trend of up and down regulated proteins compared to untreated cells are shown in Figure 6C. Protein identification was performed by MALDI TOF-MS/MS analysis. We successfully identified 118 protein spot, corresponding to 83 proteins (Supplementary Table 2). Several proteins were found in different isoforms and then detected in multiple spots. In order to construct protein-protein interaction networks regulated by AgNPsEPS $^{\text {aer }}$ we used STRING database [44]. Figure 7A depict the interaction networks of the AgNPs-EPS ${ }^{\text {aer }}$ regulated
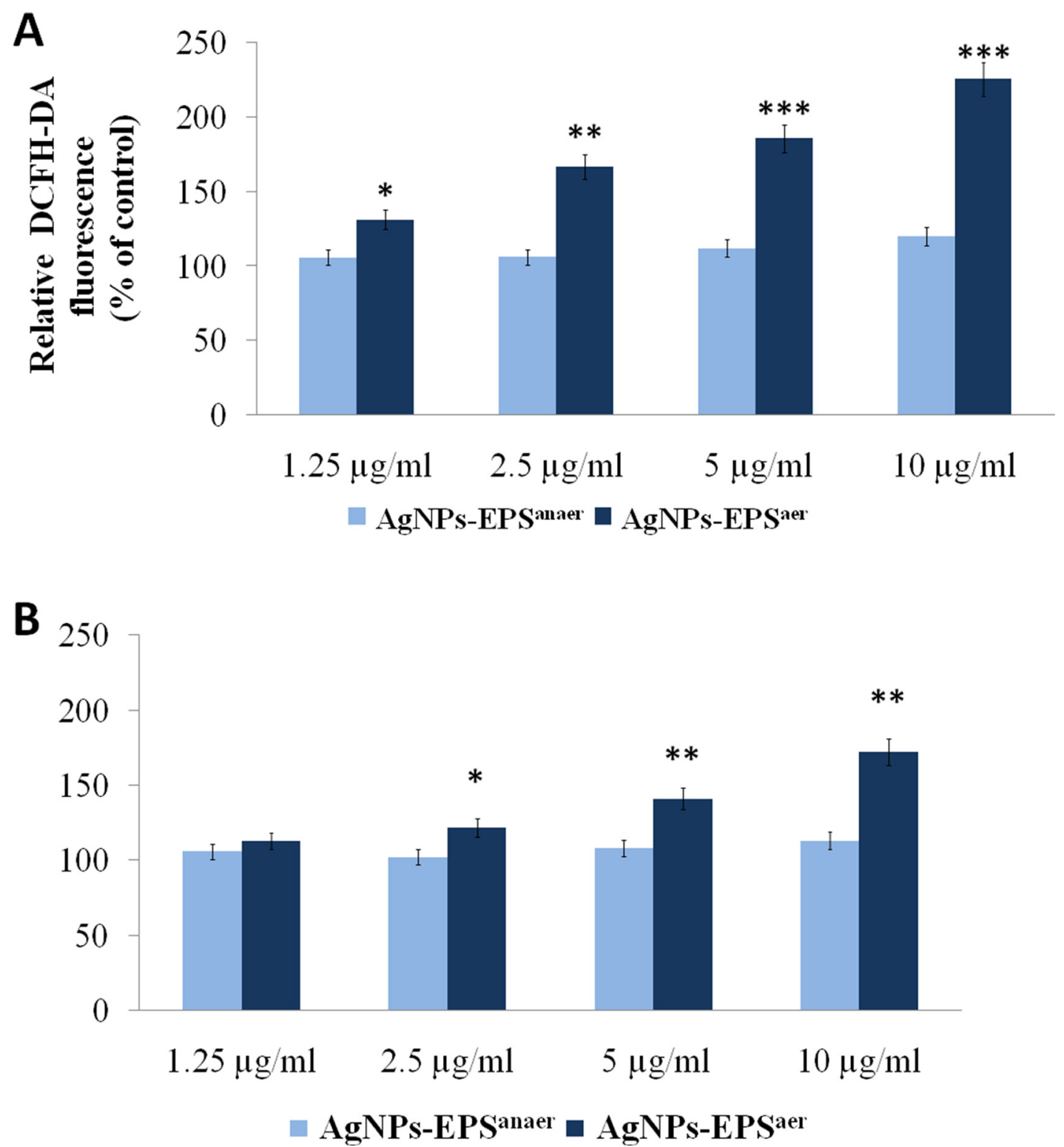

Figure 4: Effect of AgNPs-EPS treatment on intracellular ROS generation. ROS were measured using DCFH-DA (A) and DHE (B) and quantified through spectrofluorometry. Data were normalized for cell number determined by MTT assay and expressed as percentage in respect to the untreated cells used as control. Statistical significance was assessed by the Student's $t$-test: ${ }^{*} p<0.05$ was considered significant, ${ }^{* *} p<0.01$ highly significant and ${ }^{* * *} p<0.001$ very highly significant. The data are expressed as mean value $\pm \mathrm{SD}$. 
protein, in which is possible to observe a group of proteins biologically connected, with several interactions among themselves. Functional enrichments analysis performed by using gene ontology terms, allow us to better understand the molecular mechanisms underlying the cellular responses triggered by AgNPs-EPS ${ }^{\text {aer }}$ : Figure 7B shows the protein clusters involved in different biological processes (protein folding, oxido-reduction processes, regulation of cell death, response to stress and in particular to reactive oxygen stress), molecular functions (essentially binding capability e.g proteins and nucleic acid, and oxidoreductase activity) and cellular component (extracellular exosomes, intracellular organelles lumen, mitochondrion, nucleus). Moreover, the biological meaning and functional pathways were extracted by using DAVID Bioinformatics Resources [45], where a high number of proteins with specific biochemical functions were found. In particular, the majority of the identified proteins can be classified into 5 different groups namely: mitochondrial proteins, endoplasmic reticulum lumen
A
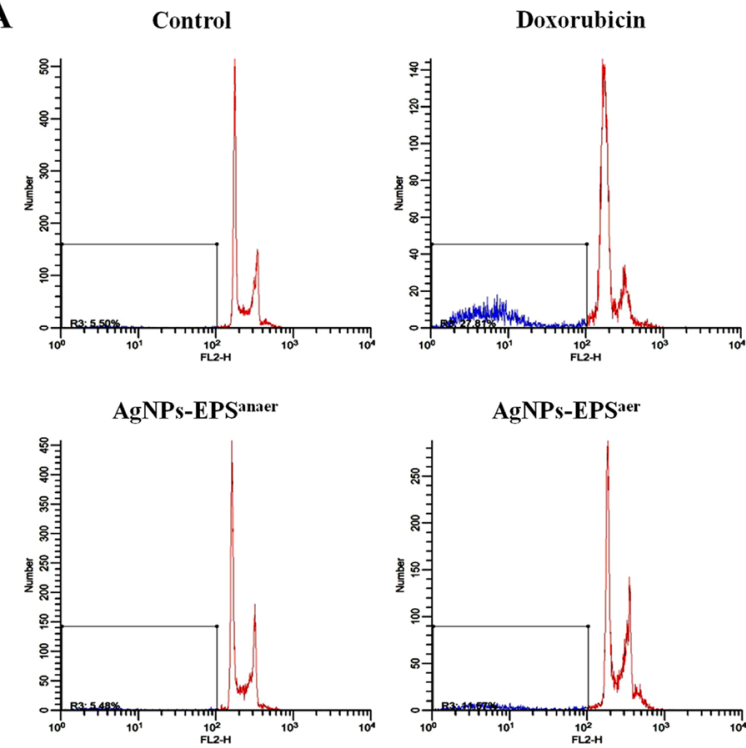

AgNPs-EPS ${ }^{\text {aer }}$

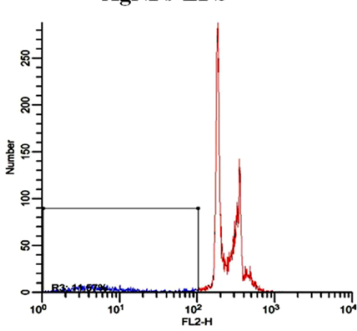

C
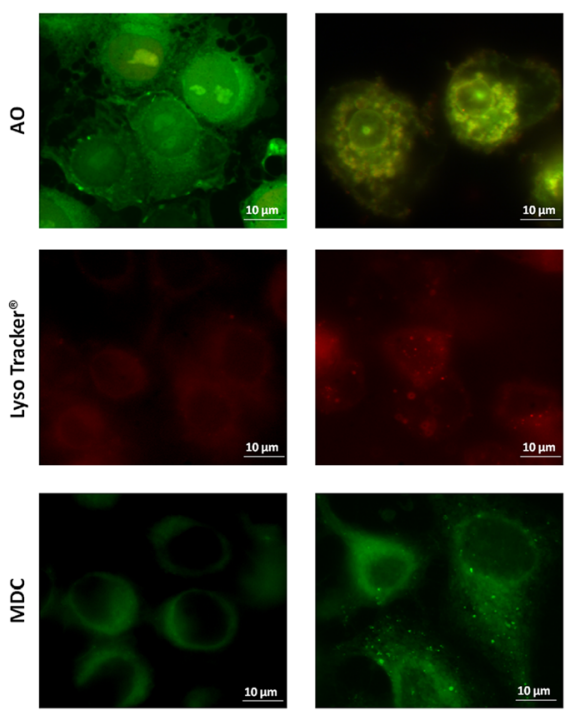

Control

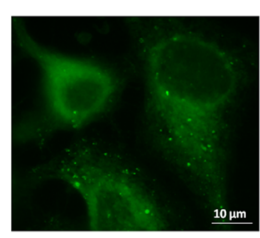

AgNPs-EPS $^{\text {aer }}$

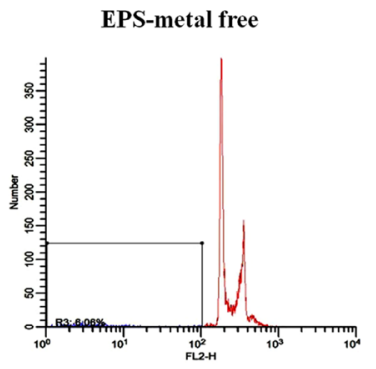

B
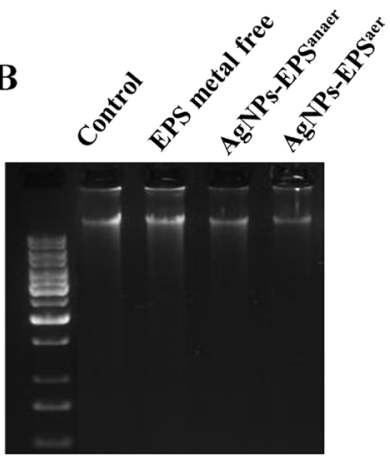

D
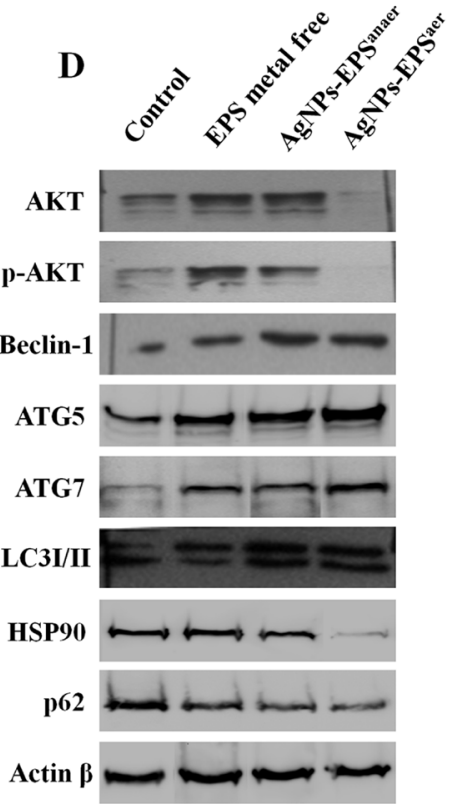

Figure 5: Detection of Apoptosis and autophagy on SKBR3 cells treated with AgNPs-EPS. (A) Flow cytometry analysis of DNA distribution in propidium iodide-stained cells. (B) Genomic DNA separated on 1\% agarose gels, and visualized by gel red staining. (C) Fluorescence micrographs after Acridine Orange, Monodancylcadaverine and Lysotracker staining for labeling of acidic vesicular organelles (AVO), autophagosomes/autolysosomes respectively. (D) Western blot analysis showing the effect of AgNPs-EPS treatment on the expression of autophagic protein markers. Actin was used as loading control. 
proteins, proteins involved in regulation of apoptosis, proteins involved in the response to oxidative stress and glycolytic proteins. Figure 8 reports the histograms of protein level variations following the AgNPs-EPS aer treatment, compared with the untreated cells. Interestingly, proteomics results highlights important pathways involved in the mechanism of action of AgNPs-EPS ${ }^{\text {aer }}$ on SKBR3 cells and strengthens our previous observations on its biological function. In particular the differentially proteins identified can efficiently explain the cellular effects of AgNPs-EPS ${ }^{\text {aer }}$. Infact accumulating evidence suggests that protein folding and generation of reactive oxygen species (ROS) as a byproduct of protein oxidation in the ER are closely linked events [46]. Persistent oxidative stress and protein misfolding initiate cell death cascades, involving mitochondrial disfunctions; moreover, mitochondrial turnover is dependent on autophagy. Collectively, the dow-regulation of glycolitic enzymes suggest a partial reversion of the so called Warburg effect, first described by Otto Warburg, and considered an important cancer hallmark [47].

\section{Uptake of AgNPs-EPSaer by SKBR3 cells}

TEM micrographs (Figure 9) showed that AgNPsEPS $^{\text {aer }}$ treated cells exhibited numerous endosomes with
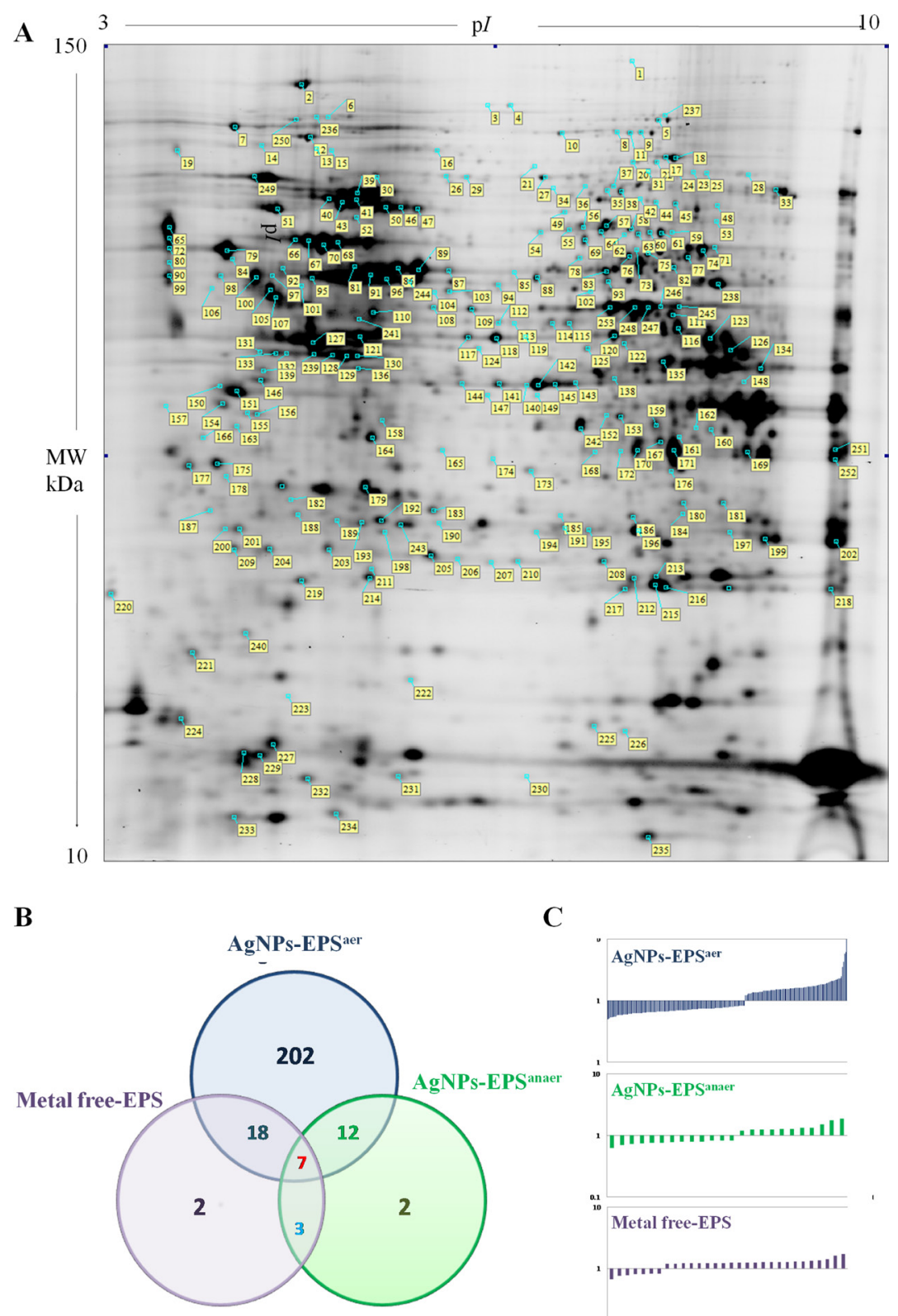

C

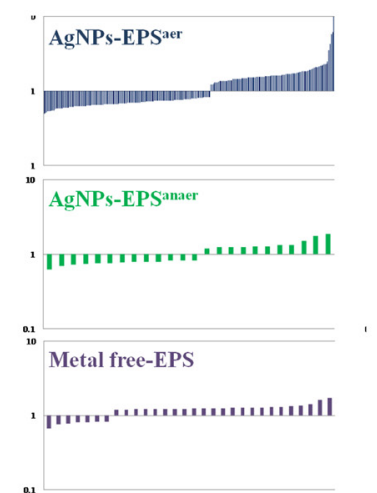

Figure 6: Differential proteomic analysis of SKBR3 cells treated with AgNPs-EPS. (A) Proteomic map of SKBR3 control cells. Labels indicate the 253 differential protein spots. (B) Eulero Venn diagram showing the differentially expressed proteins selected on the threshold setting in the studied groups; (C) Histograms showing the up and down-regulated proteins plotted as fold change compared to untreated cells. 
engulfed nanoparticles and autophagic vacuoles filled with structures resembling mitochondria. Moreover numerous exocytic vesicles and pseudopodia were also observed. Only few nanoparticles were observed within the nucleus, because the matrix is more electron dense than the cytoplasm and it is more difficult to distinguish the single silver nanoparticles.

\section{Determination of total silver in cell fractions}

Inductively coupled plasma atomic emission spectrometry (ICP), was used to measure the concentration of total silver in cell fractions (nuclei, mitochondria, lysosomes and membranes) obtained by sequential centrifugation of AgNPs treated cells for 24

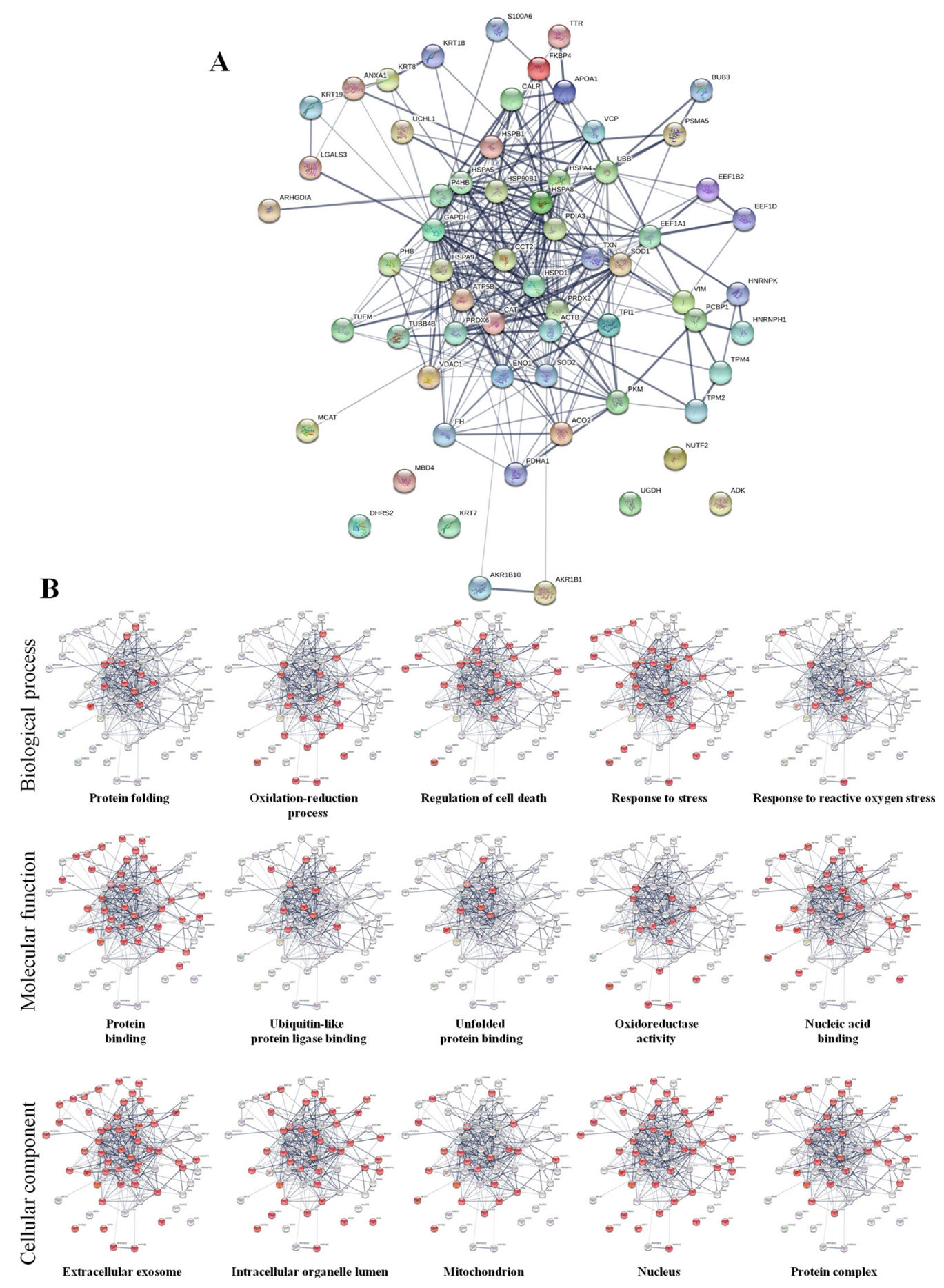

Figure 7: Protein-protein interaction networks. (A) Functional interaction network of AgNPs-EPS ${ }^{\text {aer }}$ regulated proteins created by String algorithm. Stronger interactions are represented by thicker lines. (B) Miniatures of functional network sorted by enriched Gene Ontology terms: biological processes, molecular functions and cellular components. For each group the involved proteins are highlighted in red. 
Mitochondrion
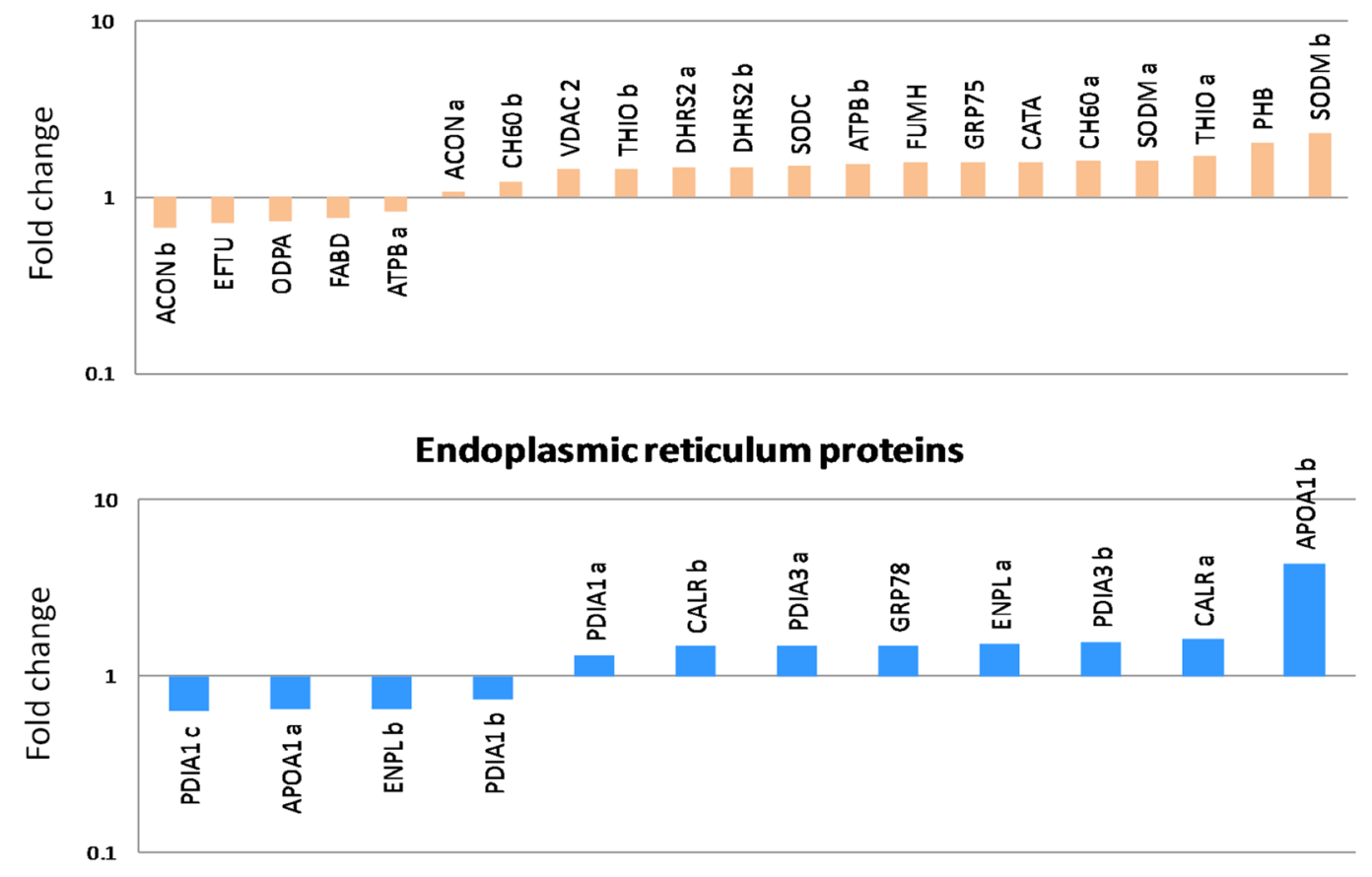

\section{Regulation of apoptosis}

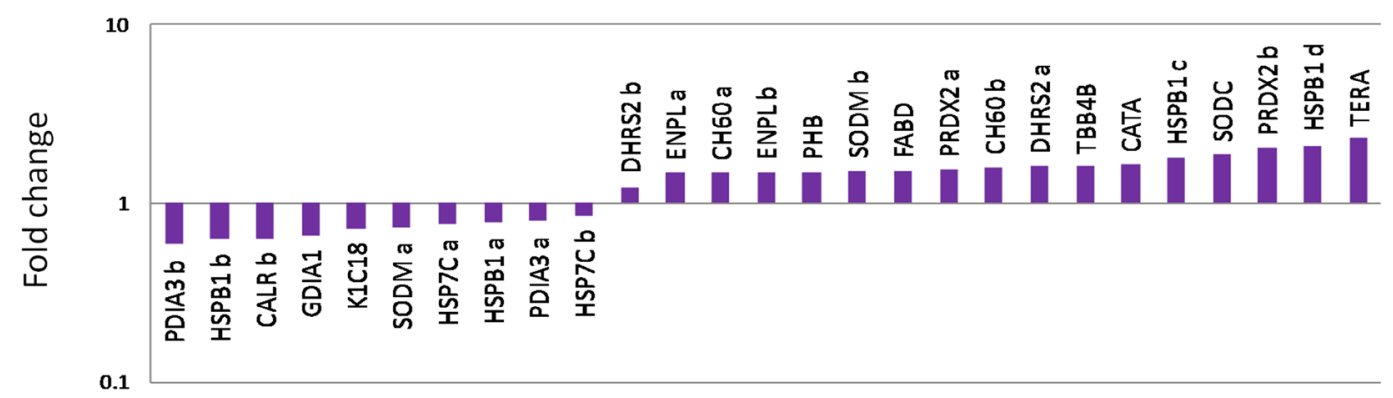

Cellular response to oxidative stress

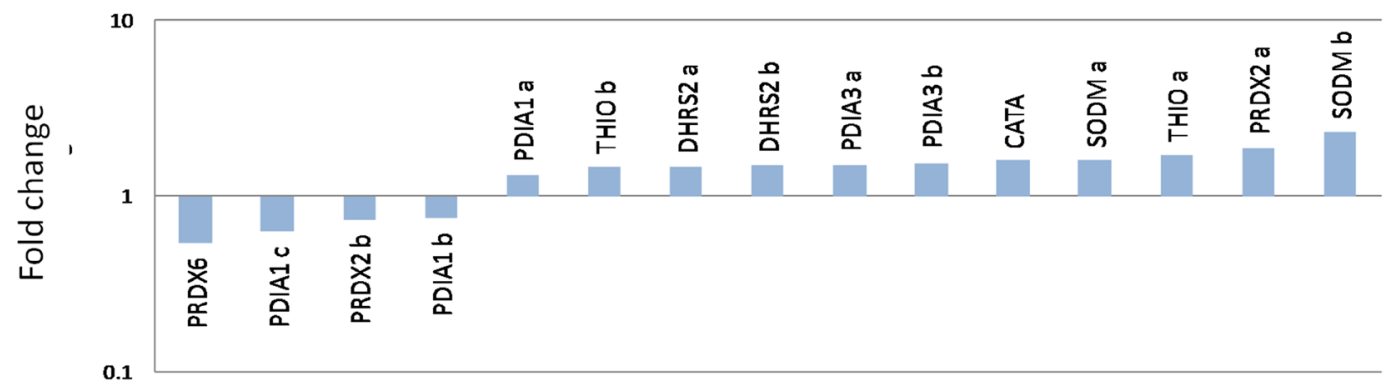

Glycolysis

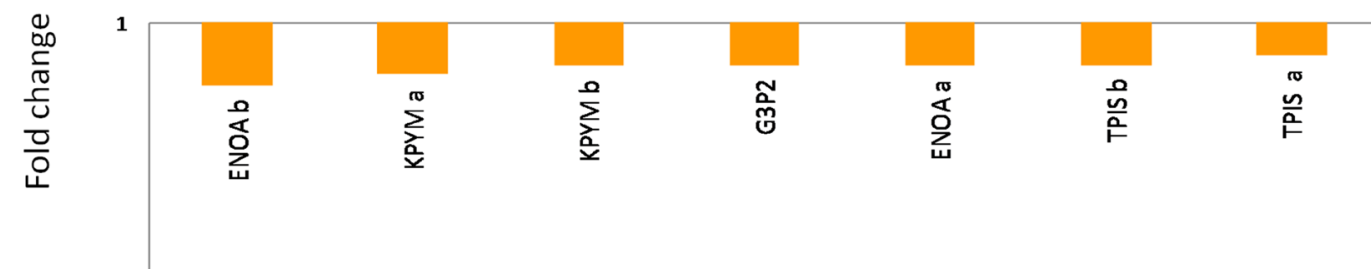

Figure 8: Histograms of the differentially identified proteins in SKBR3 AgNPs-EPS ${ }^{\text {aer }}$ treated cells, sorted into functional classes and plotted as fold change compared to untreated cells. 
h. As expected, higher Ag concentration was detected in AgNPs-EPS ${ }^{\text {aer }}$ treated cells compared to AgNPsEPS $^{\text {anaer }}$ treated cells. Interestingly, tot-Ag was detected only in mitochondria and nuclei fractions, with a higher concentration in mitochondria with respect to nuclei (Figure 10), suggesting a prominent role of mitochondria

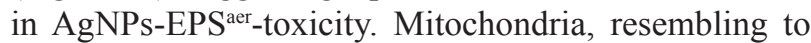
bacteria, likely have a similar mechanism of transportation for $\mathrm{Ag}^{+}$in E.coli [24].

\section{Excitation emission spectroscopy of DNA}

The interaction of $\mathrm{Ag}^{+}$with DNA was studied with EEM spectroscopy. For this purpose the three dimensional excitation emission matrix (EEM) fluorescence spectroscopy was used to characterise and distinguish the DNA from the Ag-DNA. This fluorescence method is specific, sensitive and reliable enough to characterise and distinguish even similar synthetic organic dyes [48]. The fingerprints of EEM spectra of DNA extracted from cell line SKBR3 show significant changes in the $\mathrm{E}_{\mathrm{ex}} / \mathrm{E}_{\mathrm{em}}$ contour for exposed and unexposed cells. The intrinsic fluorescence of DNA from untreated cells which are excited with $\mathrm{E}_{\mathrm{ex}}=270 \mathrm{~nm}$ produces two sharp $\mathrm{E}_{\mathrm{em}}$ peaks: the first peak centred at $315 \mathrm{~nm}$ and the second peak centred at $604 \mathrm{~nm}$ (Figure 11). The same pattern was detected in exposed cells to $\mathrm{IC}_{50}$ of AgNPs-EPS ${ }^{\text {aer }}$ for $24 \mathrm{~h}$ (data not shown). Accordingly to ICP results, these results reinforce the idea that at $24 \mathrm{~h}$ of treatment DNA is not the primary target of AgNPs-EPs ${ }^{\text {aer }}$ treatment. The EEM contours have significantly changed when the cell remains exposed to AgNPs-EPs ${ }^{\text {aer }}$ with an higher concentration (50 $\mathrm{mg} / \mathrm{ml})$ or for a longer time $(48 \mathrm{~h})$. In these conditions the first peak doubled in two peaks namely (1a) and (1b), with an important shift of peak (1a) from 315 to $327 \mathrm{~nm}$ and with a new peak (1b) at $373 \mathrm{~nm}$. The second DNA peak was shifted from $604 \mathrm{~nm}$ of the control cells to 619 nm of silver exposed cells. The intensity (RFU) of peaks, the shifts, and in particular the doubling of first peak are to be considered as caused by DNA interaction with $\mathrm{Ag}+$.
These peaks are similar to those produced in vivo with E.coli [24] and in vitro by $\mathrm{Ag}^{+}$complexed by synthetic DNA oligonucleotides [49, 50].These results could indicate that in the long-time treatment with AgNPs-EPs ${ }^{\text {aer }}$ increase and/or stabilise the interaction of silver with DNA inducing cell death [51].

\section{DISCUSSION}

Metal nanoparticles are versatile agents with a variety of applications and in particular in nanomedicine for highly sensitive diagnostic assays, thermal ablation, radiotherapy enhancement including drug and gene delivery [14]. In this study, two biogenerated AgNPs-EPS has been used to induce toxicity and to study the mechanisms of toxicity in a breast cancer cell line SKBR3. Both AgNPs-EPS were already characterized and used for antimicrobial activities [24]. The most important characteristics of silver nanoparticles used in this study are: the spherical shape with an average size of $11 \pm 5 \mathrm{~nm}$. The concentration of total silver in AgNPs-EPS ${ }^{\text {aer }}$ is $12.1 \%$ while in AgNPsEPS $^{\text {anaer }}$ is $5.2 \%$, whereas the relative productions of AgNPs-EPS ${ }^{\text {aer }}$ and AgNPs-EPS ${ }^{\text {anaer }}$ were 170 and $312 \mathrm{mg} / \mathrm{L}$, respectively. Information on reactivity of AgNPs and the release of $\mathrm{Ag}(\mathrm{I})$ species at the AgNPs-EPS/water interface was obtained by combining SECM and voltammetric experiments [25]. It is interesting to note that the amount of $\mathrm{Ag}(\mathrm{I})$ released from AgNPs-EPS ${ }^{\text {aer }}$ is sensibly higher (4-6 times) than that of AgNPs-EPS ${ }^{\text {anaer }}$. The composition of the AgNPs-EPS materials are differently rich of Ag(I)-NPs or $\mathrm{Ag}(0)-\mathrm{NPs}$. As expected, $\mathrm{Ag}(\mathrm{I})$ forms predominate in the AgNPs-EPS ${ }^{\text {aer }}$ material, conceivable due to the presence of oxygen, which could promote the oxidation of $\operatorname{Ag}(0) \mathrm{NPs}$ to provide easier diffusible $\mathrm{Ag}(\mathrm{I})$ species. Accordingly to their chemical and physical properties, AgNPs-EPS ${ }^{\text {aer }}$ showed most important biological activity in term of cytotoxic, morphologic and proteomic effects. We also verified a selective action of AgNPs-EPS ${ }^{\text {aer }}$ in SKBR3 breast cancer cells compared to the non tumoral mammary cell line HB2. Since cancer cells display an altered metabolism

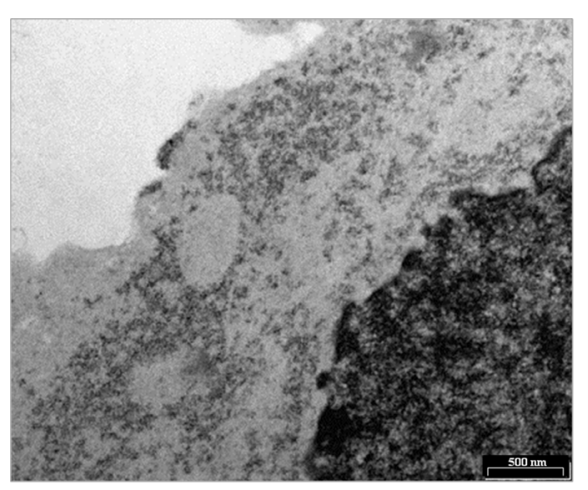

Control
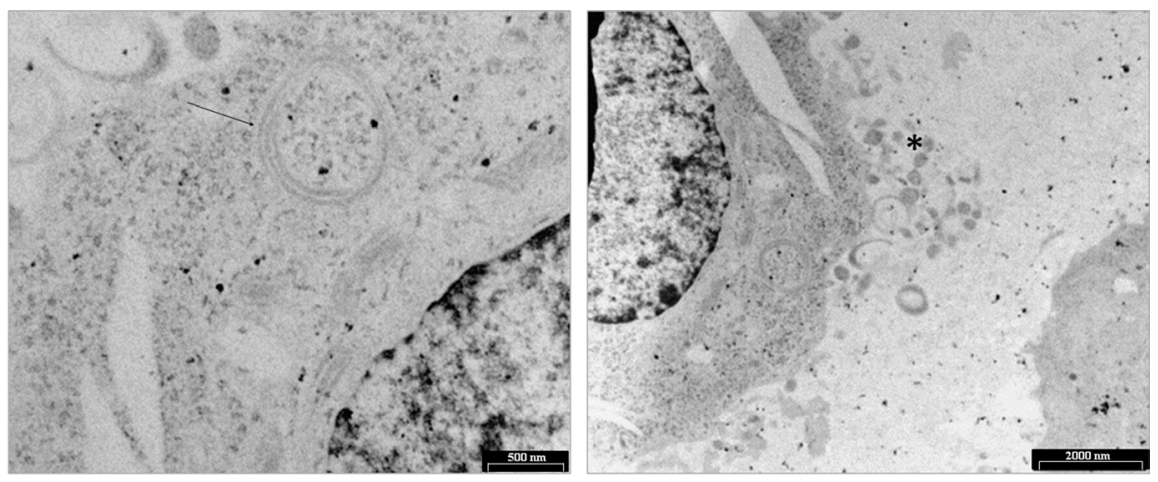

AgNPs-EPS ${ }^{a e r}$

Figure 9: TEM micrographs of SKBR3 cells treated with AgNPs-EPS ${ }^{\text {aer }}$. Arrow indicates endosomes while asterisk indicates vesicles and pseudopodia. 
and increased glucose uptake, irrespective of oxygen availability (aerobic glycolysis or Warburg effect) [52], we believe that they are able to detect the sugars present in the EPS and to pick it with greater efficiency compared to normal cells. Recently, carbohydrates have been considered as biomimetic functional molecules on the surface of nanoparticles [53] also because they trigger cellular uptake via specific receptors or endocytosis. TEM analysis showed that AgNPs-EPS ${ }^{\text {aer }}$ uptake occurs through endocytosis and, as suggested by colony formation assay, the effects are evident after $1 \mathrm{~h}$ of treatment. Moreover, AgNPs-EPS ${ }^{\text {aer }}$ treatment inhibited migration and invasion capability of tumoral cells, considered as a cancer hallmark, suggesting a potential anticancer effect.

Findings from several studies reported that both the AgNPs and $\mathrm{Ag}^{+}$released by $\mathrm{AgNPs}$ are involved in the mechanism of cytotoxicity in different ways: infact, AgNPs probably provide a perfect surface outside the mitochondria for the univalent reduction of oxygen to superoxide from electron through the electron transport chain. On the other hand, $\mathrm{Ag}^{+}$binds to proteins and DNA, interfering with their functions [54]. Moreover, ROS generation and oxidative stress occur as an early event leading to NP-induced toxicity [38].

Our results point in the same direction suggesting that the cellular response to AgNPs-EPS ${ }^{\text {aer }}$ exposure is the sum of events triggered by a direct effect of the cellular uptake of AgNPs, as verified by TEM analysis, induction of intracellular ROS and an indirect effect of free $\mathrm{Ag}^{+}$ ions released mainly in mitochondria and secondarily in the nuclei, where they interact with DNA. To the best

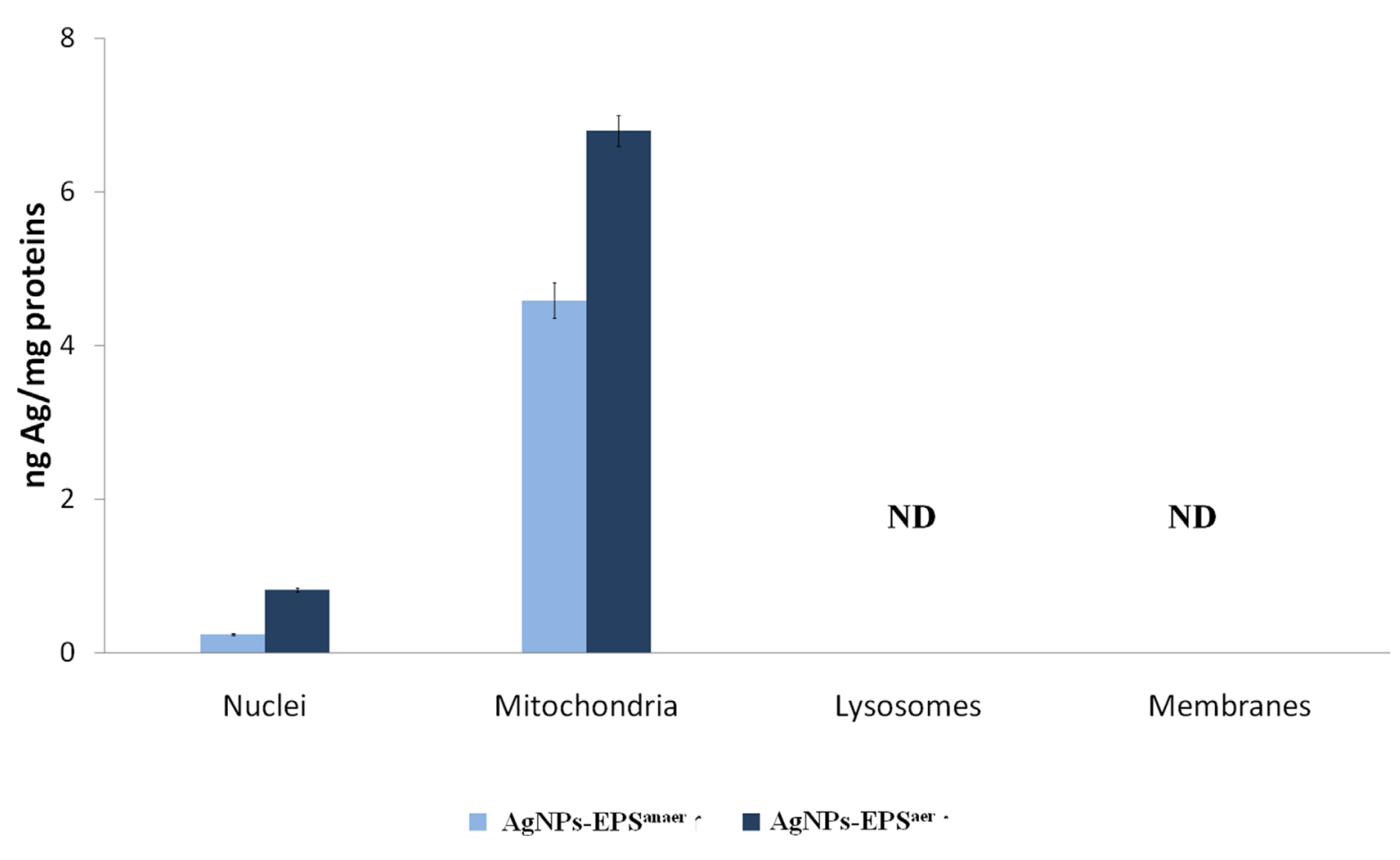

Figure 10: Determination of total silver by ICP in cell fractions. Data were normalized for protein concentration. ND means not detected. of our knowledge this is the first study reporting qualiquantitative evidences about the effects of siver ions released by nanoparticles in different cell compartments.

It is generally accepted that ROS induce autophagy and/or apoptosis. Moreover, it has been documented that autophagy may act as enabler of apoptosis, contributing in certain morphological and cellular events that take place in apoptotic cell death [55]. Autophagic cell death has morphologic and biochemical features distinguishing it from both apoptosis and necrosis. Autophagy consists of several sequential steps starting with the autophagosome formation and then progresses to autophagolysosomes through the fusion of acidic lysosomes with autophagosomes [56-58]. Several proteins can be used as markers to study autophagic flux: in particular, during autophagy, ATG proteins (eg ATG5 and ATG7) and Beclin -1, have an essential role in the autophagosome formation [59]. Later, autophagosomes (LC3-containing vacuoles) fuse with lysosomes to cause the degradation of their contents. The protein p62/SQSTM1 binds directly to LC3 and is itself degraded [60,61]. Moreover, inhibition of HSP90 plays an important role in autophagy inducing degradation of Hsp90 client proteins, such as AKT $[62,63]$. PI3K/AKT/mTOR axis downregulation lead to the activation of autophagy and the inhibition of cell proliferation, also [63]. We found that SKBR3 treated with AgNPs-EPS ${ }^{\text {aer }}$ underwent morphologic and biochemical changes consistent with the induction of autophagy and secondarily of apoptosis, as suggested by the upregulation of lysosomes, autophagolysosomes and 
acidic vescicular organelles, the down regulation of AKT, p-AKT, HSP90 and p62 the increment of ATG5, ATG7 and beclin-1 and the conversion of LC3-I to LC3-II. Concerning the apoptosis, only the $11 \%$ of treated cells underwent to apoptotic cell death and accordingly, no DNA fragmentation was evident in our analysis at $24 \mathrm{~h}$, although the increment of $\mathrm{Ag}^{+}$-DNA binding was evident after $48 \mathrm{~h}$ of treatment.

Several evidences suggested that activation of autophagy, is also dependent by the accumulation of oxidatively damaged proteins and subsequent endoplasmic reticulum stress, or mitochondrial damage [34, 64-66]. Our proteomic results are in agreement with these observations. The differentially proteins identified so far, highlights important pathways involved in the mechanism of action of AgNPs-EPS ${ }^{\text {aer }}$. The endoplasmic reticulum (ER) is a well-orchestrated protein-folding machine composed of protein chaperones, proteins that catalyze protein folding, and sensors that detect the presence of misfolded or unfolded proteins. The protein folding and generation of reactive oxygen species (ROS) as a byproduct of protein oxidation in the ER are closely linked events, and persistent oxidative stress and protein misfolding initiate cell death. Autophagy is emerging as an important mediator of pathological responses and engages in cross-talk with ROS. Oxidative stress is inseparably linked to mitochondrial dysfunction, as mitochondria are both generators of and targets for reactive species. Moreover, the mitochondrial turnover is dependent on autophagy. We believe that proteomic pathways disclosed in this study represent an important advance about the mechanisms of AgNPs-EPS ${ }^{\text {aer }}$ induced toxicity according to a modern omic-research direction in cancer therapy.

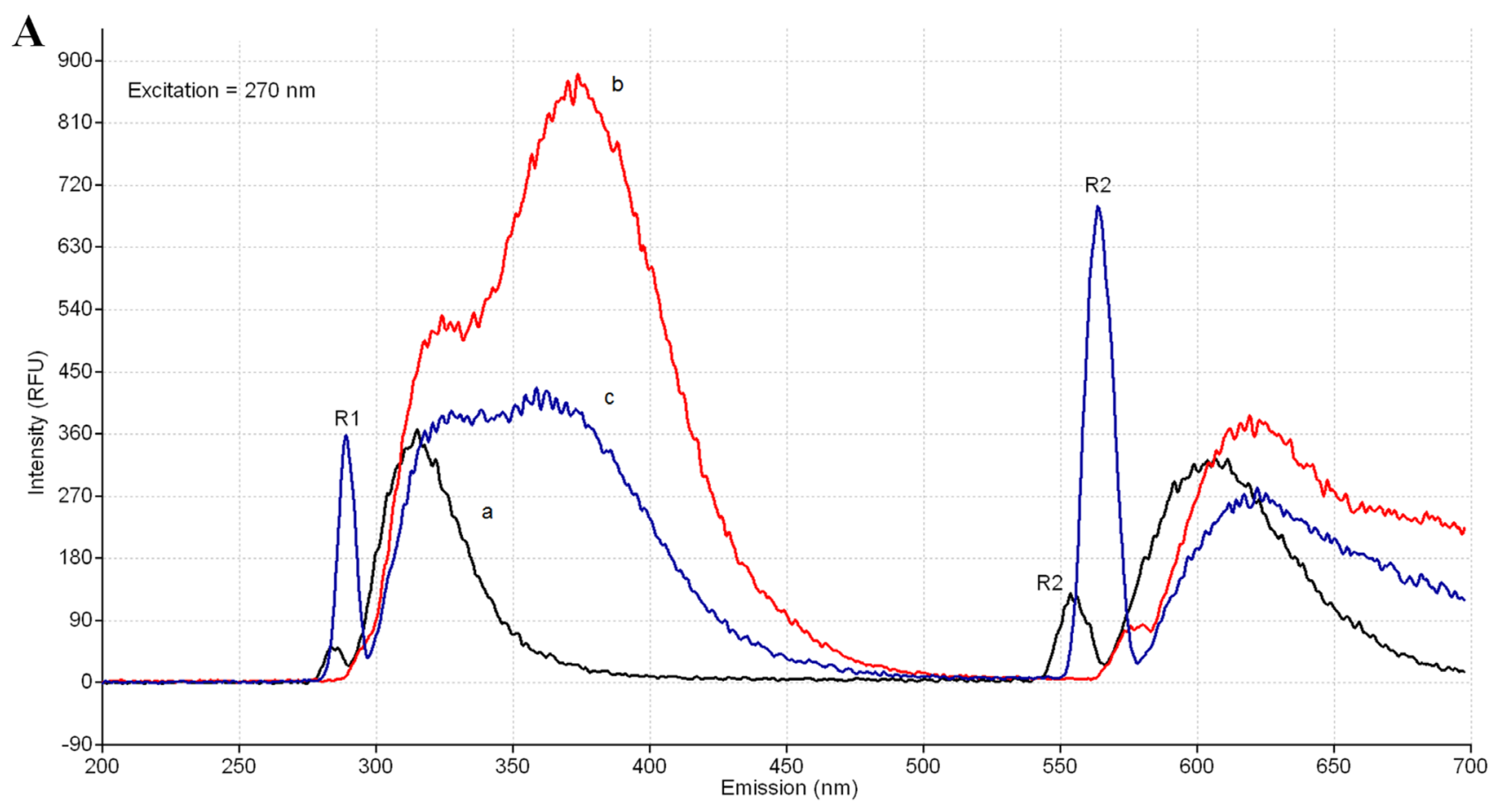

B

\begin{tabular}{|c|c|c|c|c|c|c|}
\hline \multirow[t]{2}{*}{ a) Control } & peak 1a (nm) & Intensity (RFU) & peak $1 b(\mathrm{~nm})$ & Intensity (RFU) & peak $2(\mathrm{~nm})$ & Intensity (RFU) \\
\hline & 315 & 368 & n.d. & n.d. & 604 & 320 \\
\hline \multirow[t]{2}{*}{ b) AgNPs-EPSaer $5 \mu \mathrm{g} / \mathrm{ml}$ at $48 \mathrm{~h}$} & peak 1a $(\mathrm{nm})$ & Intensity (RFU) & peak $1 \mathrm{~b}(\mathrm{~nm})$ & Intensity (RFU) & peak $2(\mathrm{~nm})$ & Intensity (RFU) \\
\hline & 327 & 522 & 373 & 881 & 619 & 388 \\
\hline \multirow[t]{2}{*}{ c) $\mathrm{AgNPs}-E P S$ aer $50 \mu \mathrm{g} / \mathrm{ml}$ at $24 \mathrm{~h}$} & peak $1 \mathrm{a}(\mathrm{nm})$ & Intensity (RFU) & peak $1 b(\mathrm{~nm})$ & Intensity (RFU) & peak $2(\mathrm{~nm})$ & Intensity (RFU) \\
\hline & 327 & 394 & 373 & 390 & 619 & 275 \\
\hline
\end{tabular}

Figure 11: Excitation-emission spectroscopy of DNA. Determination of intrinsic DNA fluorescence. The DNA was extracted from SKBR3 treated and untreated with AgNPs-EPsaer. The Eex was set at $270 \mathrm{~nm}$ and the Eem were ranging from 200 to $700 \mathrm{~nm}$. The relative fluorescence units (RFU) of intensities and the 3 emission peaks (1a, 1b and 2) were reported. R1 and R2 corresponded to the Rayleigh scattering peaks. 
In conclusion, our results suggest a so-called "Trojan-horse" mechanism [67], in which AgNPs-EPS ${ }^{\text {aer }}$ internalized within the cells access the mitochondria and nuclei where release Ag ions, which determine oxidative stress and cell death. The crosstalk between autophagy, redox signaling and mitochondrial dysfunction is not well understood and further efforts are necessary to analyze the oxidative stress-ER stress-mitochondria connectivity and apoptosis/autophagy. These interesting results encourage further studies to highlight the in vivo effects on breast cancer cells.

\section{MATERIALS AND METHODS}

\section{Culture conditions production of two AgNPs- EPS}

Cells of $K$. oxytoca DSM 29614 strain were stored in cryovials at $-80^{\circ} \mathrm{C}$ in $25 \%$ glycerol solution until they were revitalized in Nutrient Broth (Difco), When the strain was grown under anaerobic and aerobic conditions the NAC medium, buffered at $\mathrm{pH} 7.8$, was used $\left(2.5 \mathrm{~g} / \mathrm{L} \mathrm{NaHCO}_{3}\right.$, $1.5 \mathrm{~g} / \mathrm{L}$ ammonium acetate, $1.5 \mathrm{~g} / \mathrm{L} \mathrm{MgSO}_{4} .7 \mathrm{H}_{2} \mathrm{O}, 0.6 \mathrm{~g} / \mathrm{L}$ $\mathrm{NaH}_{2} \mathrm{PO}_{4}, 0.1 \mathrm{~g} / \mathrm{L}$ potassium acetate, and $14.7 \mathrm{~g} . \mathrm{l}^{-1}$ sodium citrate) [22]. The anaerobic medium was cooled under $\mathrm{N}_{2}$ flux and then was sealed. An overnight pre inoculum of cells was prepared and inoculated both into this oxygenfree medium and that aerated medium with $10 \mathrm{ml}$ of DSM 29614 culture $\left(\mathrm{OD}_{600 \mathrm{~nm}}=1.0\right)$ and incubated at $30^{\circ} \mathrm{C}$. After 3 days incubation for aerobic medium and after 6 days for anaerobic medium, $50 \mathrm{mg}$ of $\mathrm{Ag}^{+}$, such as $\mathrm{AgNO}_{3}$, was added in both cultures. The growth of the strain was followed by determining total proteins according to Bradford micro-method recommended by Bio-Rad reagent. After 2 days from $\mathrm{Ag}^{+}$additions both precipitates were recovered by a gently centrifugation (1000 $g$ x 20 min). The precipitated cells were removed by further centrifugations. The polysaccharide fraction was washed twice with milliQ water and the polysaccharide was precipitated with $70 \%$ ethanol solution overnight at $4^{\circ} \mathrm{C}$. Both ethanol precipitates were dried out under vacuum and grinded in a mortar. Thereafter the two biogenerated silver nanoparticles were designed as AgNPs-EPS ${ }^{\text {aer }}$ and of AgNPs-EPS ${ }^{\text {anaer }}$.

\section{Cell culture and treatments}

SKBR3, 8701-BC, HT29 and HCT116, were cultured in RPMI 1640 media (Gibco, Paisley, UK), while $\mathrm{CaCo} 2$ cells were cultured in DMEM medium, supplemented with $10 \%$ heat-inactivated fetal bovine serum and $100 \mathrm{U} / \mathrm{mL}$ penicillin and $100 \mu \mathrm{g} / \mathrm{mL}$ streptomycin, as already described [33, 68-71]. The human mammary epithelial cell line HB2, already characterized for proteomic profile [70], was grown in Dulbecco's modified Eagle's medium (DMEM) supplemented with $10 \%$ fetal bovine serum, $100 \mathrm{U} / \mathrm{mL}$ penicillin and $100 \mu \mathrm{g} / \mathrm{mL}$ streptomycin, hydrocortisone $(5 \mu \mathrm{g} / \mathrm{mL})$ and insulin $(10 \mu \mathrm{g} / \mathrm{mL})$. All culture cells were maintained at $37^{\circ} \mathrm{C}$ and $5 \% \mathrm{CO}_{2}$. Cells were seeded at cell density of $2 \times 10^{4} / \mathrm{cm}^{2}$, and to $70 \%$ confluence they were treated with different concentrations of AgNPsEPS $^{\text {anaer }}$, AgNPs-EPS $^{\text {aer }}$ and metal-free EPS (produced in absence of metal), for $24 \mathrm{~h}$ for all experiments. Where not expressed, the cells were treated with the corresponding $\mathrm{IC}_{50}$ values.

\section{Cell viability assay}

The cytotoxic activity of both NPs-EPS was determined using MTT assay (Promega, Madison, WI, USA), as previously described [69, 72]. Briefly, cells were plated at $5 \times 10^{3}$ cells/well in 96-well plates. NPsEPS, diluted to the desiderated concentrations in culture medium, were added to the wells with respective vehicle control $\left(\mathrm{H}_{2} \mathrm{O}\right)$. Doxorubicin hydrochloride (Sigma, st. Louis, MO) was used as reference drug. After $24 \mathrm{~h}$ of incubation $20 \mu \mathrm{L}$ of the Cell titer $96^{\circledR} \mathrm{AQ}_{\text {ueous }}$ reagent was added to each well after three washes with phosphate buffer saline (PBS) and incubated for $1-4 \mathrm{~h}$ at $37^{\circ} \mathrm{C}$ in a $\mathrm{CO}_{2}$ incubator. The absorbance was recorded at 490 $\mathrm{nm}$ using a 96-well plate reader $\left(\operatorname{Spark}^{\circledR} 20 \mathrm{M}\right.$, Tecan Trading AG, Switzerland). The percentage of cell viability was calculated with respect to untreated control cells for each treatment after subtraction of the blank. The concentration necessary for $50 \%$ of growth inhibition $\left(\mathrm{IC}_{50}\right)$ was calculated using a dose-response model, which was obtained from sigmoidal fitting of response curves of percent inhibition versus logarithmic concentration of DOSs using Graph Pad Prism software. Each result was the mean value of three different experiments performed in triplicate.

\section{Colony formation assay}

This assay identifies the cell populations that survive following a cytotoxic treatment. Cells were seeded at a density of 200, 400 and 800 cells in 6-well plates. After 2 $\mathrm{h}$, the cells were treated for $1 \mathrm{~h}$ and for $24 \mathrm{~h}$ with 5 and 50 $\mu \mathrm{g} / \mathrm{L}$ of AgNPs-EPS. At the end of the incubation period, medium was replaced with fresh medium and cells were incubated for 10 days. Colonies were fixed and stained with a mixture of $6.0 \%$ glutaraldehyde and $0.5 \%$ crystal violet and then counted microscopically using $10 \times$ high power fields. Clonogenic index was then calculated as the ratio of plating efficiency of treated cells on wells divided by the number of cells in the control wells.

\section{Cell migration}

Cell migration was studied by using an in vitro scratch assay. SKBR3 cells were seeded on 24-well tissue 
culture plates and grown to $100 \%$ confluence. Wounds were created by scraping the monolayer of cells with a sterile pipette tip, washed with PBS to remove the floating cells and incubated with fresh medium in the presence or absence of AgNPs-EPS. The images of scratched area were captured (at 40× magnification) using an inverted microscope equipped with digital camera immediately after wounding and after 6 and $24 \mathrm{~h}$. The scratched area was calculated by Image J software.

\section{Gelatin zymography}

SKBR3 cells $\left(5 \times 10^{4}\right.$ cells/well $)$ were seeded on 6-well plates, grown to $90 \%$ of confluence and treated for $24 \mathrm{~h}$ with AgNPs-EPS $\mathrm{IC}_{50}$ in a serum-free medium. Conditioned media were collected, centrifuged to remove cellular debris, dialyzed and lyophilized. Equal amounts of total proteins $(5 \mu \mathrm{g})$ were separated by electrophoresis, on a 7.5\% sodium dodecyl sulfate (SDS)-polyacrylamide gel containing $0.1 \%$ gelatin, under non-reducing conditions. After electrophoresis, the gels were washed for $1 \mathrm{~h}$ with a buffer containing $50 \mathrm{mM}$ Tris- $\mathrm{HCl}, \mathrm{pH} 7.5$ and $2.5 \%$ Triton X-100, to remove the SDS and then incubated with activation buffer containing $50 \mathrm{mM}$ Tris- $\mathrm{HCl}, \mathrm{pH} 7.5,150$ $\mathrm{mM} \mathrm{NaCl}, 5 \mathrm{mM} \mathrm{CaCl}_{2}$, for $18 \mathrm{~h}$ at $37^{\circ} \mathrm{C}$. Gel was stained with Coomassie Brilliant Blue G 250 and de-stained with $\mathrm{H}_{2} \mathrm{O}$ milliQ. The bands intensity were measured with Image $\mathrm{J}$ software.

\section{Morphological assessment and Acridine orange/ Ethidium bromide (AO/EB)}

SKBR3 cells were seeded in 12 well culture plates with a cell density of $1 \times 10^{5}$ cells/well. After $24 \mathrm{~h}$ cells were incubated for $24 \mathrm{~h}$ with the $\mathrm{IC}_{50}$ concentration of the AgNPs-EPS ${ }^{\text {aer }}$, and observed for morphological changes assessment under a phase contrast inverted microscope (Carl Zeiss) at 400X magnification. For AO/EB, the cells were seeded at the same conditions in a cover slip and after treatments, cells were washed twice with PBS and stained for few minutes with $200 \mu \mathrm{L}$ of the Acridine Orange $(100 \mu \mathrm{g} / \mathrm{mL})$, Ethidium Bromide $(100 \mu \mathrm{g} / \mathrm{mL})$ mixture $(1: 1$, $\mathrm{v} / \mathrm{v})$. Cells were immediately observed under a fluorescent microscopy (Carl Zeiss) at 630X magnification.

\section{Evaluation of ROS generation}

Intracellular ROS levels were measured by using 2', $7^{\prime}$-dichlorodihydrofluorescein diacetate (DCFHDA) and Dihydroethidium (DHE) assays. DCFH-DA is routinely used to measure intracellular generation of $\mathrm{H}_{2} \mathrm{O}_{2}$ and other oxidants; it is a cell-permeable probe, hydrolyzed intracellularly to the DCFH. Twoelectron oxidation of DCFH results in the formation of a fluorescent product, dichlorofluorescein (DCF). DHE is another widely used probe for detecting intracellular
$\mathrm{O}_{2}^{-}$. The red fluorescence formed from the two-electron oxidation product, is usually equated to intracellular superoxide formation. SKBR3 cells were plated in 96 well plates at a density of $5 \times 10^{3} / \mathrm{well}$, allowed to growth overnight and incubated for $24 \mathrm{~h}$ with different AgNPsEPSs concentrations. At the end the medium was replaced with the culture medium containing DCFH-DA $(10 \mu \mathrm{M})$ and DHE $(10 \mu \mathrm{M})$ and incubated for $30 \mathrm{~min}$ at $37^{\circ} \mathrm{C}$. Then the medium was replaced with PBS and the fluorescence intensity was analyzed by spectrofluorimeter with an excitation of $488 \mathrm{~nm}$ and emission wavelength of $525 \mathrm{~nm}$ for DCFH-DA and an excitation of $540 \mathrm{~nm}$ and emission wavelength of $590 \mathrm{~nm}$ for DHE. Data normalization was performed with parallel MTT assay.

\section{DNA extraction and flow cytomety}

DNA was extracted from SKBR3 treated cells as previously described [73], with some modifications. The cells were detached from the flasks with trypsin and suspended in $0.5 \mathrm{ml}$ of TE buffer $(100 \mathrm{mM}$ Tris- $\mathrm{HCl}$, $100 \mathrm{mM}$ EDTA pH 8). $50 \mu \mathrm{l}$ of $10 \%$ SDS and $25 \mu \mathrm{l}$ of $1 \mathrm{mg} / \mathrm{ml}$ Proteinase K were added to the cell suspension and incubated for 30 minutes at $55^{\circ} \mathrm{C}$. Nucleic acids were extracted using phenol-chloroform, precipitated with $1 / 10 \mathrm{~V} 3 \mathrm{M} \mathrm{Na}$-acetate and $2 \mathrm{~V}$ absolute ethanol and resuspended in $100 \mu \mathrm{l}$ TE buffer. The same quantity of extracted DNA was loaded on a $1 \%$ agarose gel prepared in $0.5 \mathrm{X}$ TE buffer containing gel red. Gel was visualized under UV light using a Bio-Rad Trans illuminator and photographed by using a Polaroid camera.

Apoptosis of SKBR3 cells after treatment with $\mathrm{IC}_{50}$ of AgNPs-EPS for $24 \mathrm{~h}$ was analyzed by flow cytometry essentially as described by Riccardi [74]. Briefly cells were fixed in 70\% ethanol, washed in PBS and resuspended in DNA extraction buffer (200 mM Na2HPO4, 0.1\% Triton $\mathrm{X}-100)$. After staining with Propidium Iodide $(1 \mu \mathrm{g} / \mathrm{mL})$ for $30 \mathrm{~min}$, fluorescence intensity was acquired in the FL2 channel by flow cytometry on a FACSCalibur flow cytometer (BD, New Jersey, USA). Data acquisition was performed with CellQuest Pro (BD) software, and analyzed with WinList software (Verity Software House, Topsham, USA).

\section{Fluorescence staining with Acridine Orange (AO), monodansylcadaverine (MDC) and Lysotracker $^{\circledR}$}

SKBR3 cells were grown on coverslips and treated for $24 \mathrm{~h}$ with the $\mathrm{IC}_{50}$ concentration of AgNPsEPS ${ }^{\text {aer }}$. Acidic vesicular organelles (AVOs) were labeled with $1 \mu \mathrm{g} / \mathrm{ml}$ of Acridine Orange, autophagosomes and autolysosomes with $0.05 \mathrm{mM}$ of MDC (Sigma, St. Louis, MO, USA) while acidic compartments were labeled by incubating the cells with $75 \mathrm{nM}$ of LysoTracker ${ }^{\circledR}$ (Molecular Probes, Life Technologies) in the culture 
media for $1 \mathrm{~min}$ at RT. After incubation, cells were washed several times with PBS and immediately analyzed by fluorescence microscopy using the appropriate filter system.

\section{Western blotting analysis}

SKBR3 cells were treated for $24 \mathrm{~h}$ with $\mathrm{IC}_{50}$ concentrations of AgNPs-EPS and with $200 \mu \mathrm{g} / \mathrm{ml}$ of freemetal EPS. After washing with PBS, cells were carefully scraped and incubated on ice for $30 \mathrm{~min}$ Lysis buffer containing $7 \mathrm{M}$ urea, $2 \mathrm{mM}$ Thiourea, $0.4 \% \mathrm{w} / \mathrm{v}$ CHAPS, $1 \% \mathrm{w} / \mathrm{v}$ 1,4-dithioerythritol (DTE) and 30mM TRIZMA base, $\mathrm{pH}$ 8.5. The total cellular lysate was centrifuged at $14,000 \mathrm{rpm}$ for $10 \mathrm{~min}$ to clear cell debris and protein concentration determined by Bradford assay, as already reported [75, 76]. Protein samples $(20 \mu \mathrm{g} /$ lane $)$ were subjected to SDS polyacrylamide gel electrophoresis, then transferred to a nitrocellulose membrane (HyBond ECL, Amersham) and stained with Ponceau S (Sigma Aldrich). Western blotting analyses were performed using a rabbit polyclonal antibodies for Akt 1-2-3 and pAkt 1-2-3, a goat polyclonal antibody for Beclin 1, a mouse monoclonal antibody for Actin $\beta$, HSP90, MMP2 and MMP9 by Santa Cruz Biotechnology (Santa Cruz, CA, USA), a rabbit polyclonal antibody for LC3 by Sigma Aldrich and a rabbit polyclonal antibodies for p62, ATG5 and ATG7 by Cell Signaling Technology. Following incubation with the appropriate peroxidase-linked antibody, the reaction was revealed by the ECL detection system, using high performance films (Hyperfilm ECL, Amersham), as already described $[68,77]$. The correct protein loading was ascertained by red Ponceau staining and immunoblotting for $\operatorname{Actin} \beta$.

\section{Subcellular separation for Ag+ release}

After treatments, SKBR3 cells were detached from the flasks with a scaper and resuspended in Sucrose buffer (5mM Tris- $\mathrm{HCl} \mathrm{pH} 7.4,0.32 \mathrm{M}$ Sucrose and $0.001 \mathrm{mg} /$ $\mathrm{mL}$ Protease/phosphatase inhibitor). Nuclei were pelleted by centrifugation at $1000 \mathrm{~g}$ for 20 minutes; mitochondria from the post-nuclear supernatants were recovered by centrifugation at $8500 \mathrm{~g}$ for 30 minutes; lysosome by centrifugation at $20000 \mathrm{~g}$ for 30 minutes and membranes by centrifugation at $105000 \mathrm{~g}$ for 90 minutes. The $\mathrm{Ag}^{+}$ release from subcellular components was measured by scanning electrochemical microscopy and anodic stripping voltammetry (ASV) using a CHI920B workstation (CH Instruments), as already described [24, 25].

\section{Determination of total Ag}

Total silver was determined in $1 \mathrm{mg}$ sample of pulverized AgNPs-EPS ${ }^{\text {aer }}$, AgNPs-EPS ${ }^{\text {anaer }}$ and in subcellular fractions of breast cancer cell line SKBR3.
Samples were digested with $2 \mathrm{~mL}$ of aqua regia, heating at $60^{\circ}$ until a solution was obtained. Total Ag was determined by Inductively Coupled Plasma Atomic Emission Spectrometry, ICP-AES (Optima 3100, Perkin Elmer) [78].

\section{D-DIGE analysis}

Protein samples were labeled for 2D-DIGE analysis using CyDyeTM DIGE minimal labeling kit (GE Healthcare, Sweden), according to manufacturer's recommendations as already described [18]. An internal standard was generated by combining equal amounts of samples and labeled with Cy2 Protein samples $(50 \mu \mathrm{g})$ were labeled with 200 pmol of CyDye on ice in the dark for $30 \mathrm{~min}$. Labeling reaction was quenced by addition of $1 \mu \mathrm{l}$ of $10 \mathrm{mM}$ lysine, and incubation was continued on ice for $10 \mathrm{~min}$, in the dark. The first dimensional separation was performed at $20^{\circ} \mathrm{C}$ on commercial sigmoidal immobilized $\mathrm{pH}$ gradient strips (IPG), $18 \mathrm{~cm}$ long with $\mathrm{pH}$ range 3.5 to 10 (Pharmacia). Strips were rehydrated in $8 \mathrm{M}$ urea, 2\% CHAPS, $10 \mathrm{mM} \mathrm{DTE}$, and $0.5 \%$ carrier ampholytes (Resolyte 3.5-10). The isoelectrofocusing was carried out by linearly increasing voltage from 200 to $3500 \mathrm{~V}$ during the first $3 \mathrm{hr}$, after which focusing was continued at $8000 \mathrm{~V}$ for $8 \mathrm{hr}$, as already described [33, 68-72, 75-77, 79-84]. After the first dimension separation the IPG strips were equilibrated with a solution containing $6 \mathrm{M}$ urea, $30 \%$ glycerol, $2 \%$ SDS, 0.05M Tris-HCl pH 6.8, and 2\% DTE for $12 \mathrm{~min}$, to resolubilize proteins and reduce disulphuric bonds. The -SH groups were then blocked by substituting the DTE with $2.5 \%$ iodoacetamide in the equilibrating buffer. The focused proteins were then separated on 9-16\% linear gradient polyacrylamide gels (SDSPAGE) using a DALT six (GE Healthcare) apparatus with a constant current of $40 \mathrm{~mA} / \mathrm{gel}$ at $10^{\circ} \mathrm{C}$. Images were acquired with a Typhoon FLA 9500 scanner (GE Healthcare), using specific emission filters, and analyzed by the Image Master 2D Platinum 7 software (GE Healthcare). Protein spots showing more than 1.3 fold change in spot volume (increased for upregulation or decreased for down-regulation), with a statistically significant ANOVA value $(p \leq 0.05)$, were considered differentially represented and further identified by MS analysis. After the acquisition, each gels were stained with ammoniacal silver nitrate, as already described [80].

\section{In-gel digestion and MS analysis of tryptic digests}

Spots of interest were manually picked and mass spectrometric sequencing was carried out after in-gel digestion, using sequencing-grade trypsin (20 $\mu \mathrm{g} / \mathrm{vial})$, 
according to the method of Shevchenko et al. with some modifications as already described [85]. The tryptic peptide extracts were dried in a vacuum centrifuge and dissolved in $0.1 \%$ trifluoroacetic acid (TFA). Peptide mixtures were desalted by $\mu$ Zip-TipC18 (Millipore, MA)). The matrix, R-cyano-4-hydroxycinnamic acid (HCCA), was purchased from Sigma-Aldrich. A saturated solution of HCCA $(1 \mu \mathrm{L})$ at $2 \mathrm{mg} / 200 \mu \mathrm{L}$ in $\mathrm{CH} 3 \mathrm{CN} / \mathrm{H} 2 \mathrm{O}(50: 50(\mathrm{v} / \mathrm{v}))$ containing $0.1 \%$ TFA was mixed with $1 \mu \mathrm{L}$ of peptide solution and loaded onto the MALDI target plate and left to dry. A peptide calibration standard was spotted separately onto the MALDI target plate. Mass spectra were obtained using an Ultraflex MALDITOF-TOF (Bruker Daltonics, Bremen, Germany) or a MALDI-TOF Voyager DE-PRO (Applied Biosystems) mass spectrometer. Peptide mass fingerprinting was compared to the theoretical masses from the Swiss-Prot or NCBI sequence databases using Mascot (http://www.matrixscience.com/). Typical search parameters were as follows: 50 ppm of mass tolerance, carbamidomethylation of cysteine residues, one missed enzymatic cleavage for trypsin, a minimum of four peptide mass hits was required for a match, methionine residues could be considered in oxidized form, no restriction was placed on the isoelectric point of the protein, and a protein mass range from 5 to $100 \mathrm{kDa}$ was allowed.

\section{Transmission electron microscopy (TEM) analysis}

Cells were grown to confluence in a 12-well plate and treated with appropriate concentrations of both AgNPs-EPS for $24 \mathrm{~h}$, washed in $0.075 \mathrm{M}$ phosphate buffer $\mathrm{pH} 6.9$ and immediately fixed in a solution of $3 \%$ glutaraldehyde in cacodylate buffer $0,066 \mathrm{M} \mathrm{pH} 7.2$ for $30 \mathrm{~min}$ as already described [72]. Then the cells were dehydrated using increasing concentrations of ethanol (10, $30,50,70$ and $100 \%$ ) at room temperature and gradually infiltrated in Spurr's low viscosity embedding resin and polymerized at $70^{\circ} \mathrm{C}$ for $8 \mathrm{~h}$. After polymerization, specimens were sectioned with an ultramicrotome (model LKB III) using a diamond knife. The thin sections were collected on copper grids, stained for $10 \mathrm{~min}$ in $2 \%$ uranyl acetate and $5 \mathrm{~min}$ in lead citrate and then they were observed by Transmission Electron Microscopy (PHILIPS 268 Morgagni, FEI ) operating under standard conditions.

\section{Fluorescence spectra of DNA}

The emission-excitation (EEM) spectra of DNA were recorded by Luminescent Spectrometer (Perkin Elmer LS 55). The instrument was equipped with a Xenon discharge lamp equivalent to $20 \mathrm{KW}$ for $8 \mu$ s duration pulse, wide at half eight minor $10 \mu$ s with excitation slit $5 \mathrm{~nm}$ and emission slit $5 \mathrm{~nm}$. The extracted DNA was suspended in $1 \mathrm{ml}$ milliQ and transferred in cuvette for fluorescence analyses. The EEM scan spectra were measured by scanning simultaneously both the excitation
$\left(\mathrm{E}_{\mathrm{ex}}\right)$, which ranged from 200 to $320 \mathrm{~nm}$, and the emission $\left(\mathrm{E}_{\mathrm{em}}\right)$, which ranged from 200-700 nm. The EEM contour maps were obtained by original equipped computer software. The relative fluorescence units (RFU) of peaks were also determined.

\section{Statistical analysis}

Results are presented as means \pm standard error. Data were analysed using Student's $t$-test. $p<0.05$ was considered significant; $p<0.01$ was considered highly significant and $p$ $<0.001$ was considered very highly significant.

\section{ACKNOWLEDGMENTS}

This work was partially supported by Grants from MIUR - Italy (FIRB-MERIT n.RBNE08YYBM) to S.F., University of Palermo (n.2014-ATE-0185) to S.F. and P.C, and by $5 \times 1000$ contribution to COBS.

2D-DIGE and MALDI-TOF-TOF analysis was performed using the instruments of Advanced Technologies Network (ATeN) Center at the University of Palermo, acquired in the frame of "Mediterranean Center for Human Health Advanced Biotechnologies" (MedCHHAB) project (Project code: PONa3_00273 - Avviso MIUR D.D. n. 254/Ric del 18/05/2011).

We are grateful to Dott. Antonella D'Anneo, Dott. Fabiana Geraci and Dott. Melchiorre Cervello for providing some reagents.

\section{CONFLICTS OF INTEREST}

Authors declare no conflicts of interest.

\section{REFERENCES}

1. Lanone S, Boczkowski J. Biomedical applications and potential health risks of nanomaterials: molecular mechanisms. Curr Mol Med. 2006; 6:651-63.

2. Pérez-Herrero E, Fernández-Medarde A. Advanced targeted therapies in cancer: Drug nanocarriers, the future of chemotherapy. Eur J Pharm Biopharm. 2015; 93:52-79. https://doi.org/10.1016/j.ejpb.2015.03.018.

3. Hanley C, Layne J, Punnoose A, Reddy KM, Coombs I, Coombs A, Feris K, Wingett D. Preferential killing of cancer cells and activated human $\mathrm{T}$ cells using $\mathrm{ZnO}$ nanoparticles. Nanotechnology. 2008; 19:295103. https:// doi.org/10.1088/0957-4484/19/29/295103.

4. Conde J, Doria G, Baptista P. Noble metal nanoparticles applications in cancer. J Drug Deliv. 2012; 2012:751075. https://doi.org/10.1155/2012/751075.

5. Rai MK, Deshmukh SD, Ingle AP, Gade AK. Silver nanoparticles: the powerful nanoweapon against multidrugresistant bacteria. J Appl Microbiol. 2012; 112:841-52. https://doi.org/10.1111/j.1365-2672.2012.05253.x. 
6. Poulose S, Panda T, Nair PP, Théodore T. Biosynthesis of silver nanoparticles. J Nanosci Nanotechnol. 2014; 14:2038-49.

7. Russo M, Meli A, Sutera A, Gallo G, Chillura Martino D, Lo Meo P, Noto R. Photosynthesized silverpolyaminocyclodextrin nanocomposites as promising antibacterial agents with improved activity RSC Adv. 2016; 6:40090-40096. https://doi.org/10.1039/C6RA00042H

8. Vigneshwaran N, Nachane RP, Balasubramanya RH, Varadarajan PV. A novel one-pot 'green' synthesis of stable silver nanoparticles using soluble starch. Carbohydr Res. 2006; 341:2012-8. https://doi.org/10.1016/j.carres.2006.04.042

9. Narayanan KB, Sakthivel N. Biological synthesis of metal nanoparticles by microbes. Adv Colloid Interface Sci. 2010; 156:1-13. https://doi.org/10.1016/j.cis.2010.02.001.

10. Deepak V, Umamaheshwaran PS, Guhan K, Nanthini RA, Krithiga B, Jaithoon NM, Gurunathan S. Synthesis of gold and silver nanoparticles using purified URAK. Colloids Surf B Biointerfaces. 2011; 86:353-8. https://doi. org/10.1016/j.colsurfb.2011.04.019.

11. Mittal AK, Bhaumik J, Kumar S, Banerjee UC. Biosynthesis of silver nanoparticles: Elucidation of prospective mechanism and therapeutic potential. J Colloid Interface Sci. 2014; 415:39-47. https://doi.org/10.1016/j. jcis.2013.10.018.

12. Iravani S, Korbekandi H, Mirmohammadi SV, Zolfaghari B. Synthesis of silver nanoparticles: chemical, physical and biological methods. Res Pharm Sci. 2014; 9:385-406.

13. Hulkoti NI, Taranath TC. Biosynthesis of nanoparticles using microbes- a review. Colloids Surf B Biointerfaces. 2014; 121:474-83. https://doi.org/10.1016/j. colsurfb.2014.05.027.

14. Panacek A, Kvítek L, Prucek R, Kolar M, Vecerova R, Pizúrova N, Sharma VK, Nevecna T, Zboril R. Silver colloid nanoparticles: synthesis, characterization, and their antibacterial activity. J Phys Chem B. 2006; 110:16248-53. https://doi.org/10.1021/jp063826h.

15. Vigneshwaran N, Kathe AA, Varadarajan PV, Nachane RP, Balasubramanya RH. Biomimetics of silver nanoparticles by white rot fungus, Phaenerochaete chrysosporium. Colloids Surf B Biointerfaces. 2006; 53:55-9. https://doi. org/10.1016/j.colsurfb.2006.07.014.

16. Kanmani P, Lim ST. Synthesis and characterization of pullulan-mediated silver nanoparticles and its antimicrobial activities. Carbohydr Polym. 2013; 97:421-8. https://doi. org/10.1016/j.carbpol.2013.04.048.

17. Baldi F, Minacci A, Pepi M, Scozzafava A. Gel sequestration of heavy metals by Klebsiella oxytoca isolated from iron mat. FEMS Microbiol Ecol. 2001; 36:169-74.

18. Gallo G, Baldi F, Renzone G, Gallo M, Cordaro A, Scaloni A, Puglia AM. Adaptative biochemical pathways and regulatory networks in Klebsiella oxytoca BAS-10 producing a biotechnologically relevant exopolysaccharide during Fe(III)-citrate fermentation. Microb Cell Fact. 2012; 11:152. https://doi.org/10.1186/1475-2859-11-152.
19. Sugihara R, Yoshimura M, Mori M, Kanayama N, Hikida M, Ohmori H. Prevention of collagen-induced arthritis in DBA/1 mice by oral administration of AZ9, a bacterial polysaccharide from Klebsiella oxytoca. Immunopharmacology. 2000; 49:325-33.

20. Qiang L, Yumei L, Sheng H, Yingzi L, Dongxue S, Dake H, Jiajia W, Yanhong Q, Yuxia Z. Optimization of fermentation conditions and properties of an exopolysaccharide from Klebsiella sp. H-207 and application in adsorption of hexavalent chromium. PLoS One. 2013; 8:e53542. https:// doi.org/10.1371/journal.pone.0053542.

21. Baldi F, Marchetto D, Zanchettin D, Sartorato E, Paganelli S, Piccolo O. A bio-generated Fe(iii)-binding exopolysaccharide used as new catalyst for phenol hydroxylation. Green Chemistry. 2010; 12:1405-9. https:// doi.org/10.1039/C004967K.

22. Baldi F, Marchetto D, Paganelli S, Piccolo O. Bio-generated metal binding polysaccharides as catalysts for synthetic applications and organic pollutant transformations. $\mathrm{N}$ Biotechnol. 2011; 29:74-8. https://doi.org/10.1016/j. nbt.2011.04.012.

23. Paganelli S, Tassini R, La Sorella G, Piccolo O, Baldi F, Rathod VD. Aqueous biphasic treatment of some nitrocompounds with hydrogen in the presence of a biogenerated Pd-polysaccharide. N Biotechnol. 2015; 32:313-7. https://doi.org/10.1016/j.nbt.2015.01.010.

24. Baldi F, Daniele S, Gallo M, Paganelli S, Battistel D, Piccolo O, Faleri C, Puglia AM, Gallo G. Polysaccharide-based silver nanoparticles synthesized by Klebsiella oxytoca DSM 29614 cause DNA fragmentation in E. coli cells. Biometals. 2016; 29:321-31. https://doi.org/10.1007/s10534-016-9918-4.

25. Battistel D, Baldi F, Gallo M, Faleri C, Daniele S. Characterisation of biosynthesised silver nanoparticles by scanning electrochemical microscopy (SECM) and voltammetry. Talanta. 2015; 132:294-300. https://doi. org/10.1016/j.talanta.2014.09.023.

26. Nakkala JR, Mata R, Gupta AK, Sadras SR. Biological activities of green silver nanoparticles synthesized with Acorous calamus rhizome extract. Eur J Med Chem. 2014; 85:784-94. https://doi.org/10.1016/j.ejmech.2014.08.024.

27. Cancemi P, Buttacavoli M, D’Anna F, Feo S, Fontana RM, Noto R, Sutera A, Vitale P, Gallo G. The effects of structural changes on the anti-microbial and anti-proliferative activities of diimidazolium salts. New Journal of Chemistry. 2017; 41:3574-85. https://doi.org/10.1039/C6NJ03904A.

28. Tokarska-Schlattner M, Wallimann T, Schlattner U. Alterations in myocardial energy metabolism induced by the anti-cancer drug doxorubicin. C R Biol. 2006; 329:65768. https://doi.org/10.1016/j.crvi.2005.08.007.

29. Mahavorasirikul W, Viyanant V, Chaijaroenkul W, Itharat A, Na-Bangchang K. Cytotoxic activity of Thai medicinal plants against human cholangiocarcinoma, laryngeal and hepatocarcinoma cells in vitro. BMC Complement Altern Med. 2010; 10:55. https://doi.org/10.1186/1472-6882-10-55. 
30. Franken NA, Rodermond HM, Stap J, Haveman J, van Bree C. Clonogenic assay of cells in vitro. Nat Protoc. 2006; 1:2315-9. https://doi.org/10.1038/nprot.2006.339.

31. Hanahan D, Weinberg RA. Hallmarks of cancer: the next generation. Cell. 2011; 144:646-74. https://doi. org/10.1016/j.cell.2011.02.013.

32. Johansson $\mathrm{N}$, Ahonen $\mathrm{M}$, Kähäri VM. Matrix metalloproteinases in tumor invasion. Cell Mol Life Sci. 2000; 57:5-15. https://doi.org/10.1007/s000180050495.

33. Pucci-Minafra I, Albanese NN, Di Cara G, Minafra L, Marabeti MR, Cancemi P. Breast cancer cells exhibit selective modulation induced by different collagen substrates. Connect Tissue Res. 2008; 49:252-6. https://doi. org/10.1080/03008200802147779.

34. Navarro-Yepes J, Burns M, Anandhan A, Khalimonchuk O, del Razo LM, Quintanilla-Vega B, Pappa A, Panayiotidis MI, Franco R. Oxidative stress, redox signaling, and autophagy: cell death versus survival. Antioxid Redox Signal. 2014; 21:66-85. https://doi.org/10.1089/ ars.2014.5837.

35. Chen P, Luo X, Nie P, Wu B, Xu W, Shi X, Chang H, Li B, Yu X, Zou Z. CQ synergistically sensitizes human colorectal cancer cells to SN-38/CPT-11 through lysosomal and mitochondrial apoptotic pathway via p53-ROS crosstalk. Free Radic Biol Med. 2017; 104:280-97. https://doi. org/10.1016/j.freeradbiomed.2017.01.033.

36. Juarez-Moreno K, Gonzalez EB, Girón-Vazquez N, ChávezSantoscoy RA, Mota-Morales JD, Perez-Mozqueda LL, Garcia-Garcia MR, Pestryakov A, Bogdanchikova N. Comparison of cytotoxicity and genotoxicity effects of silver nanoparticles on human cervix and breast cancer cell lines. Hum Exp Toxicol. 2016. https://doi. org/10.1177/0960327116675206.

37. Rahman MF, Wang J, Patterson TA, Saini UT, Robinson BL, Newport GD, Murdock RC, Schlager JJ, Hussain SM, Ali SF. Expression of genes related to oxidative stress in the mouse brain after exposure to silver-25 nanoparticles. Toxicol Lett. 2009; 187:15-21. https://doi.org/10.1016/j.toxlet.2009.01.020.

38. Mao BH, Tsai JC, Chen CW, Yan SJ, Wang YJ. Mechanisms of silver nanoparticle-induced toxicity and important role of autophagy. Nanotoxicology. 2016; 10:1021-40. https://doi. org/10.1080/17435390.2016.1189614.

39. Wu H, Lin J, Liu P, Huang Z, Zhao P, Jin H, Ma J, Wen $\mathrm{L}, \mathrm{Gu} \mathrm{N}$. Reactive oxygen species acts as executor in radiation enhancement and autophagy inducing by AgNPs. Biomaterials. 2016; 101:1-9. https://doi.org/10.1016/j. biomaterials.2016.05.031.

40. Zhang XF, Gurunathan S. Combination of salinomycin and silver nanoparticles enhances apoptosis and autophagy in human ovarian cancer cells: an effective anticancer therapy. Int J Nanomedicine. 2016; 11:3655-75. https://doi. org/10.2147/ijn.s111279.

41. Farah MA, Ali MA, Chen SM, Li Y, Al-Hemaid FM, Abou-Tarboush FM, Al-Anazi KM, Lee J. Silver nanoparticles synthesized from Adenium obesum leaf extract induced DNA damage, apoptosis and autophagy via generation of reactive oxygen species. Colloids Surf B Biointerfaces. 2016; 141:158-69. https://doi.org/10.1016/j. colsurfb.2016.01.027.

42. Paglin S, Hollister T, Delohery T, Hackett N, McMahill M, Sphicas E, Domingo D, Yahalom J. A novel response of cancer cells to radiation involves autophagy and formation of acidic vesicles. Cancer Res. 2001; 61:439-44.

43. Vazquez CL, Colombo MI. Assays to assess autophagy induction and fusion of autophagic vacuoles with a degradative compartment, using monodansylcadaverine (MDC) and DQ-BSA. Methods Enzymol. 2009; 452:85-95. https://doi.org/10.1016/S0076-6879(08)03606-9.

44. Szklarczyk D, Morris JH, Cook H, Kuhn M, Wyder S, Simonovic M, Santos A, Doncheva NT, Roth A, Bork P, Jensen LJ, von Mering C. The STRING database in 2017: quality-controlled protein-protein association networks, made broadly accessible. Nucleic Acids Res. 2017; 45:D362-D8. https://doi.org/10.1093/nar/gkw937.

45. Dennis G Jr, Sherman BT, Hosack DA, Yang J, Gao W, Lane HC, Lempicki RA. DAVID: Database for Annotation, Visualization, and Integrated Discovery. Genome Biol. 2003; 4:P3.

46. Malhotra JD, Kaufman RJ. Endoplasmic reticulum stress and oxidative stress: a vicious cycle or a double-edged sword? Antioxid Redox Signal. 2007; 9:2277-93. https:// doi.org/10.1089/ars.2007.1782.

47. Warburg O. On respiratory impairment in cancer cells. Science. 1956; 124:269-70.

48. Soltzberg LJ, Okey-Igwe N, Newman R. 3D Fluorescence Characterization of Synthetic Organic Dyes American Journal of Analytical Chemistry. 2012; 3:622-31 https:// doi.org/10.4236/ajac.2012.39081.

49. Gwinn MR, Weston A. Application of oligonucleotide microarray technology to toxic occupational exposures. J Toxicol Environ Health A. 2008; 71:315-24. https://doi. org/10.1080/15287390701738509.

50. Gwinn E, Schultz D, Copp SM, Swasey S. DNA-Protected Silver Clusters for Nanophotonics. Nanomaterials (Basel). 2015; 5:180-207. https://doi.org/10.3390/nano5010180.

51. Lee W, Kim KJ, Lee DG. A novel mechanism for the antibacterial effect of silver nanoparticles on Escherichia coli. Biometals. 2014; 27:1191-201. https://doi.org/10.1007/ s10534-014-9782-z.

52. Hirschey MD, DeBerardinis RJ, Diehl AME, Drew JE, Frezza C, Green MF, Jones LW, Ko YH, Le A, Lea MA, Locasale JW, Longo VD, Lyssiotis CA, et al. Dysregulated metabolism contributes to oncogenesis. Semin Cancer Biol. 2015; 35:S129-S50. https://doi.org/10.1016/j.semcancer.2015.10.002.

53. Marradi M, Chiodo F, Garcia I, Penades S. Glyconanoparticles as multifunctional and multimodal carbohydrate systems. Chem Soc Rev. 2013; 42:4728-45. https://doi.org/10.1039/c2cs35420a. 
54. You C, Han C, Wang X, Zheng Y, Li Q, Hu X, Sun H. The progress of silver nanoparticles in the antibacterial mechanism, clinical application and cytotoxicity. Mol Biol Rep. 2012; 39:9193-201. https://doi.org/10.1007/s11033012-1792-8.

55. Li N, Xia T, Nel AE. The role of oxidative stress in ambient particulate matter-induced lung diseases and its implications in the toxicity of engineered nanoparticles. Free Radic Biol Med. 2008; 44:1689-99. https://doi.org/10.1016/j. freeradbiomed.2008.01.028.

56. Rasul A, Yu B, Khan M, Zhang K, Iqbal F, Ma T, Yang H. Magnolol, a natural compound, induces apoptosis of SGC-7901 human gastric adenocarcinoma cells via the mitochondrial and PI3K/Akt signaling pathways. Int J Oncol. 2012; 40:1153-61. https://doi.org/10.3892/ijo.2011.1277.

57. Levine B, Yuan J. Autophagy in cell death: an innocent convict? J Clin Invest. 2005; 115:2679-88. https://doi. org/10.1172/jci26390.

58. Shin SW, Kim SY, Park JW. Autophagy inhibition enhances ursolic acid-induced apoptosis in PC3 cells. Biochim Biophys Acta. 2012; 1823:451-7. https://doi.org/10.1016/j. bbamcr.2011.10.014.

59. Kang R, Zeh HJ, Lotze MT, Tang D. The Beclin 1 network regulates autophagy and apoptosis. Cell Death Differ. 2011; 18:571-80. https://doi.org/10.1038/cdd.2010.191.

60. Klionsky DJ, Abdelmohsen $\mathrm{K}$, Abe A, Abedin MJ, Abeliovich H, Acevedo Arozena A, Adachi H, Adams CM, Adams PD, Adeli K, Adhihetty PJ, Adler SG, Agam G, et al. Guidelines for the use and interpretation of assays for monitoring autophagy (3rd edition). Autophagy. 2016; 12:1-222. https://doi.org/10.1080/15548627.2015.1100356.

61. Fader CM, Colombo MI. Autophagy and multivesicular bodies: two closely related partners. Cell Death Differ. 2009; 16:70-8. https://doi.org/10.1038/cdd.2008.168.

62. Mori M, Hitora T, Nakamura O, Yamagami Y, Horie R, Nishimura H, Yamamoto T. Hsp90 inhibitor induces autophagy and apoptosis in osteosarcoma cells. Int J Oncol. 2015; 46:47-54. https://doi.org/10.3892/ijo.2014.2727.

63. Li DD, Guo JF, Huang JJ, Wang LL, Deng R, Liu JN, Feng GK, Xiao DJ, Deng SZ, Zhang XS, Zhu XF. Rhabdastrellic acid-A induced autophagy-associated cell death through blocking Akt pathway in human cancer cells. PLoS One. 2010; 5:e12176. https://doi.org/10.1371/journal.pone.0012176.

64. Smakowska E, Czarna M, Janska H. Mitochondrial ATPdependent proteases in protection against accumulation of carbonylated proteins. Mitochondrion. 2014; 19 Pt B:24551. https://doi.org/10.1016/j.mito.2014.03.005.

65. Zhao Y, Zhang CF, Rossiter H, Eckhart L, Konig U, Karner S, Mildner M, Bochkov VN, Tschachler E, Gruber F. Autophagy is induced by UVA and promotes removal of oxidized phospholipids and protein aggregates in epidermal keratinocytes. J Invest Dermatol. 2013; 133:1629-37. https://doi.org/10.1038/jid.2013.26.

66. Song S, Tan J, Miao Y, Li M, Zhang Q. Crosstalk of autophagy and apoptosis: Involvement of the dual role of autophagy under ER stress. J Cell Physiol. 2017; 232:297784. https://doi.org/10.1002/jcp.25785.

67. Hsiao IL, Hsieh YK, Wang CF, Chen IC, Huang YJ. Trojan-horse mechanism in the cellular uptake of silver nanoparticles verified by direct intra- and extracellular silver speciation analysis. Environ Sci Technol. 2015; 49:3813-21. https://doi.org/10.1021/es504705p.

68. Di Cara G, Marengo G, Albanese NN, Marabeti MR, Musso R, Cancemi P, Pucci-Minafra I. Proteomic profiling of Trastuzumab (Herceptin(R))-sensitive and -resistant SKBR3 breast cancer cells. Anticancer Res. 2013; 33:489-503.

69. Cancemi P, Albanese NN, DiCara G, Marabeti MR, Costantini F, Minafra S, Pucci-Minafra I. Multiple changes induced by fibroblasts on breast cancer cells. Connect Tissue Res. 2010; 51:88-104. https://doi. org/10.3109/03008200903100651.

70. Pucci-Minafra I, Fontana S, Cancemi P, Basiricò L, Caricato S, Minafra S. A contribution to breast cancer cell proteomics: detection of new sequences. Proteomics. 2002; 2:919-27. https://doi.org/10.1002/1615-9861(200207)2:7<919::aidprot919>3.0.co;2-p.

71. Pucci-Minafra I, Cancemi P, Fontana S, Minafra L, Feo S, Becchi M, Freyria AM, Minafra S. Expanding the protein catalogue in the proteome reference map of human breast cancer cells. Proteomics. 2006; 6:2609-25. https://doi. org/10.1002/pmic.200500627.

72. Pucci-Minafra I, Cancemi P, Di Cara G, Minafra L, Feo S, Forlino A, Tira ME, Tenni R, Martini D, Ruggeri A, Minafra S. Decorin transfection induces proteomic and phenotypic modulation in breast cancer cells 8701BC. Connect Tissue Res. 2008; 49:30-41. https://doi. org/10.1080/03008200701820443.

73. Lo Grasso L, Maffioli S, Sosio M, Bibb M, Puglia AM, Alduina R. Two Master Switch Regulators Trigger A40926 Biosynthesis in Nonomuraea sp. Strain ATCC 39727. J Bacteriol. 2015; 197:2536-44. https://doi.org/10.1128/ JB.00262-15.

74. Riccardi C, Nicoletti I. Analysis of apoptosis by propidium iodide staining and flow cytometry. Nat Protoc. 2006; 1:1458-61. https://doi.org/10.1038/nprot.2006.238.

75. Minafra L, Di Cara G, Albanese NN, Cancemi P. Proteomic differentiation pattern in the U937 cell line. Leuk Res. 2011; 35:226-36. https://doi.org/10.1016/j.leukres.2010.07.040.

76. Reichenberg E, Redlich M, Cancemi P, Zaks B, Pitaru S, Fontana S, Pucci-Minafra I, Palmon A. Proteomic analysis of protein components in periodontal ligament fibroblasts. J Periodontol. 2005; 76:1645-53. https://doi.org/10.1902/ jop.2005.76.10.1645.

77. Cancemi P, Di Cara G, Albanese NN, Costantini F, Marabeti MR, Musso R, Riili I, Lupo C, Roz E, Pucci-Minafra I. Differential occurrence of S100A7 in breast cancer tissues: a proteomic-based investigation. Proteomics Clin Appl. 2012; 6:364-73. https://doi.org/10.1002/prca.201100072.

78. Rigo C, Zamengo L, Rampazzo G, Argese E. Characterization of a former dump site in the Lagoon of 
Venice contaminated by municipal solid waste incinerator bottom ash, and estimation of possible environmental risk. Chemosphere. 2009; 77:510-7. https://doi.org/10.1016/j. chemosphere.2009.07.046.

79. Pucci-Minafra I, Fontana S, Cancemi P, Alaimo G, Minafra S. Proteomic patterns of cultured breast cancer cells and epithelial mammary cells. Ann N Y Acad Sci. 2002; 963:122-39.

80. Pucci-Minafra I, Cancemi P, Marabeti MR, Albanese NN, Di Cara G, Taormina P, Marrazzo A. Proteomic profiling of 13 paired ductal infiltrating breast carcinomas and nontumoral adjacent counterparts. Proteomics Clin Appl. 2007; 1:118-29. https://doi.org/10.1002/prca.200600334.

81. Pucci-Minafra I, Cancemi P, Albanese NN, Di Cara G, Marabeti MR, Marrazzo A, Minafra S. New protein clustering of breast cancer tissue proteomics using actin content as a cellularity indicator. J Proteome Res. 2008; 7:1412-8. https://doi.org/10.1021/pr700748m.

82. Cancemi P, Di Cara G, Albanese NN, Costantini F, Marabeti MR, Musso R, Lupo C, Roz E, Pucci-Minafra I. Largescale proteomic identification of $\mathrm{S} 100$ proteins in breast cancer tissues. BMC Cancer. 2010; 10:476. https://doi. org/10.1186/1471-2407-10-476.
83. Coppola A, Tomasello L, Pizzolanti G, Pucci-Minafra I, Albanese N, Di Cara G, Cancemi P, Pitrone M, Bommarito A, Carissimi E, Zito G, Criscimanna A, Galluzzo A, et al. In vitro phenotypic, genomic and proteomic characterization of a cytokine-resistant murine $\beta$-TC3 cell line. PLoS One. 2012; 7:e32109. https://doi.org/10.1371/journal.pone.0032109.

84. Musso R, Di Cara G, Albanese NN, Marabeti MR, Cancemi P, Martini D, Orsini E, Giordano C, Pucci-Minafra I. Differential proteomic and phenotypic behaviour of papillary and anaplastic thyroid cell lines. J Proteomics. 2013; 90:11525. https://doi.org/10.1016/j.jprot.2013.01.023.

85. Schiera G, Di Liegro CM, Puleo V, Colletta O, Fricano A, Cancemi P, Di Cara G, Di Liegro I. Extracellular vesicles shed by melanoma cells contain a modified form of H1.0 linker histone and H1.0 mRNA-binding proteins. Int J Oncol. 2016; 49:1807-14. https://doi.org/10.3892/ijo.2016.3692. 